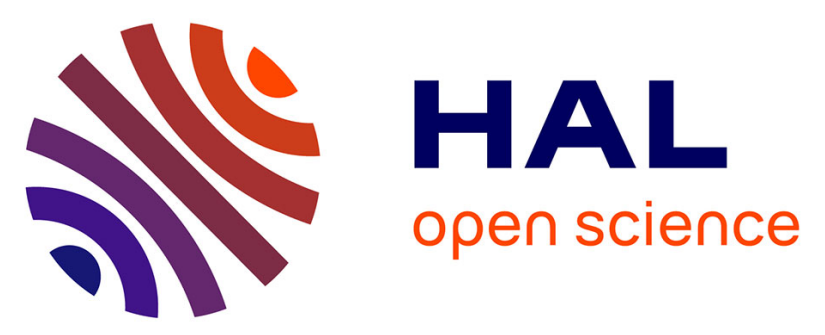

\title{
New data on the microvertebrate fauna from the Upper Jurassic or lowest Cretaceous of Ksar Metlili (Anoual Syncline, eastern Morocco)
}

Maxime Lasseron, Ronan Allain, Emmanuel Gheerbrant, Hamid Haddoumi, Nour-Eddine Jalil, Grégoire Métais, Jean-Claude Rage, Romain Vullo, Samir Zouhri

\section{To cite this version:}

Maxime Lasseron, Ronan Allain, Emmanuel Gheerbrant, Hamid Haddoumi, Nour-Eddine Jalil, et al.. New data on the microvertebrate fauna from the Upper Jurassic or lowest Cretaceous of Ksar Metlili (Anoual Syncline, eastern Morocco). Geological Magazine, 2020, 157 (3), pp.367 - 392. $10.1017 / \mathrm{s} 0016756819000761$. insu-03004245

\section{HAL Id: insu-03004245 \\ https://hal-insu.archives-ouvertes.fr/insu-03004245}

Submitted on 13 Nov 2020

HAL is a multi-disciplinary open access archive for the deposit and dissemination of scientific research documents, whether they are published or not. The documents may come from teaching and research institutions in France or abroad, or from public or private research centers.
L'archive ouverte pluridisciplinaire HAL, est destinée au dépôt et à la diffusion de documents scientifiques de niveau recherche, publiés ou non, émanant des établissements d'enseignement et de recherche français ou étrangers, des laboratoires publics ou privés. 
Geological Magazine

www.cambridge.org/geo

\section{Original Article}

Cite this article: Lasseron M, Allain R, Gheerbrant E, Haddoumi H, Jalil N-E, Métais G, Rage J-C, Vullo R, and Zouhri S. New data on the microvertebrate fauna from the Upper Jurassic or lowest Cretaceous of Ksar Metlili (Anoual Syncline, eastern Morocco). Geological Magazine https://doi.org/10.1017/ S0016756819000761

Received: 11 April 2019

Revised: 21 May 2019

Accepted: 26 May 2019

\section{Keywords:}

Africa; Gondwana; palaeoecosystems; biostratigraphy; palaeobiogeography; palaeoecology

\section{Author for correspondence:}

Maxime Lasseron,

Email: maxime.lasseron@edu.mnhn.fr

\section{New data on the microvertebrate fauna from the Upper Jurassic or lowest Cretaceous of Ksar Metlili (Anoual Syncline, eastern Morocco)}

\author{
Maxime Lasseron ${ }^{1}(0)$, Ronan Allain ${ }^{1}$, Emmanuel Gheerbrant ${ }^{1}$, Hamid Haddoumi ${ }^{2}$, \\ Nour-Eddine Jalil ${ }^{1,3}$, Grégoire Métais ${ }^{1}$, Jean-Claude Rage ${ }^{1}$, Romain Vullo ${ }^{4}$ and \\ Samir Zouhri ${ }^{5}$
}

\begin{abstract}
${ }^{1}$ CR2P - Centre de Recherche en Paléontologie - Paris, UMR 7207, MNHN-CNRS-Sorbonne Université, Muséum National d'Histoire Naturelle, 8 rue Buffon, CP38, 75005 Paris, France; ${ }^{2}$ Département de Géologie, Faculté des Sciences, Université Mohamed 1er, BP 524, 60000 Oujda, Morocco; ${ }^{3}$ Département Sciences de la Terre, Évolution des vertébrés et Paléoenvironnements, Faculté des Sciences Semlalia, Université Cadi Ayyad, Avenue Abdelkrim Khattabi, BP 511, 40000 Marrakech, Morocco; ${ }^{4}$ UMR-CNRS 6118 Géosciences Rennes, Université de Rennes 1, Campus de Beaulieu, 263 avenue du Général Leclerc, 35042 Rennes, France and ${ }^{5}$ Département de Géologie, Faculté des Sciences Aïn Chock, Université Hassan II de Casablanca, Km 8, route de l'université, 20100 Casablanca, Morocco
\end{abstract}

\begin{abstract}
The Middle Jurassic - Early Cretaceous period witnessed the emergence of some major representatives of modern continental vertebrate groups (stem lissamphibians, squamates, therian mammals and birds) and angiosperms, at a time when fragmentation of Pangaea was underway. The successive Moroccan microvertebrate faunas of Ksar Metlili (?Berriasian) and Guelb el Ahmar (Bathonian) from the Anoual Syncline significantly improve our poor knowledge of Gondwanan and especially African palaeobiodiversity at this time. They are among the richest known from the Mesozoic of Gondwana, and are well placed in northwestern Africa to record faunal interchanges with Laurasia. Here we focus on the Ksar Metlili fauna, first documented in the 1980s and most recently resampled in 2010, which produced 24541 microremains representing 47 species of 8 main groups (Chondrichthyes, Actinopterygii, Sarcopterygii, Lissamphibia, Lepidosauromorpha, Testudinata, Archosauromorpha and Synapsida). It includes remarkable taxa: the oldest stem boreosphenidan mammals from Gondwana, probably some of the last non-mammaliaform cynodonts, a basal ornithischian, possibly freshwater teleosaurid crocodylomorphs, and some of the rare occurrences of choristoderes and albanerpetontids in Gondwana. Comparison of the Ksar Metlili fauna with that of Guimarota (Kimmeridgian, Portugal) further provides evidence of numerous shared taxa of Laurasian affinities, in contrast to the occurrence of few taxa with Gondwanan affinities. This suggests complex palaeobiogeographical relationships - implying both vicariance and dispersal events - of North Africa within Gondwana at the Jurassic-Cretaceous transition. Finally, the faunal similarities with the Guelb el Ahmar fauna question the Cretaceous age of the Ksar Metlili fauna, suggesting an alternative possible Late Jurassic age.
\end{abstract}

\section{Introduction}

Continental vertebrate faunas from the Jurassic-Cretaceous transition are rare and poorly known (Cifelli et al. 1999; Clemens et al. 2007; Knoll \& Ruiz-Omeñaca, 2009; J. P. Tennant, unpub. Ph.D. thesis, Imperial College London, 2016; Tennant et al. 2016; Fig. 1). This is especially true for the Gondwanan faunas, particularly the African ones (Sigogneau-Russell et al. 1998; Rauhut \& López-Arbarello, 2009). Yet, the Jurassic-Cretaceous transition is a pivotal interval, both from evolutionary and geodynamic perspectives. The Middle Jurassic to Early Cretaceous period saw the emergence or the first diversification of some of the major modern clades of terrestrial vertebrates: modern lissamphibians and dinosaurs diversified 165 million years ago, probably after the Pliensbachian-Toarcian mass extinction event (Marjanović \& Laurin, 2007; Allain \& Aquesbi, 2008; Allain \& Läng, 2009); birds appeared 150 million years ago (Ostrom, 1976; Zhou, 2004); and the first tribosphenic therian mammal (Tribosphenida), Juramaia, has been dated as early Late Jurassic, about 160 million years ago (Ji et al. 2002; Luo et al. 2003, 2011), as have the first modern representatives of squamates, including snakes (Evans \& Jones, 2010; Caldwell et al. 2015). The angiosperms made their first radiation about 125-130 million years ago (Heimhofer et al. 2005; Hochuli et al. 2006; Berendse \& Scheffer, 2009). The Late Jurassic period was also the time of major geodynamic events involving the break-up of Pangaea, with the opening of the Neo-Tethys and Central Atlantic oceans, leading to the separation of Gondwana from Laurasia (Gheerbrant \& Rage, 2006; J. Pouech, unpub. Ph.D. thesis, Claude Bernard - Lyon 1 University, 2008; J. P. Tennant, unpub. Ph.D. thesis, 
Fig. 1. (Colour online) Continental vertebrate localities known from the Upper Jurassic (Kimmeridgian; bottom) and the Lower Cretaceous (Berriasian; top). Each point represents a locality. Modified from paleobiodb.org (Paleobiology Database Contributors, 2019).
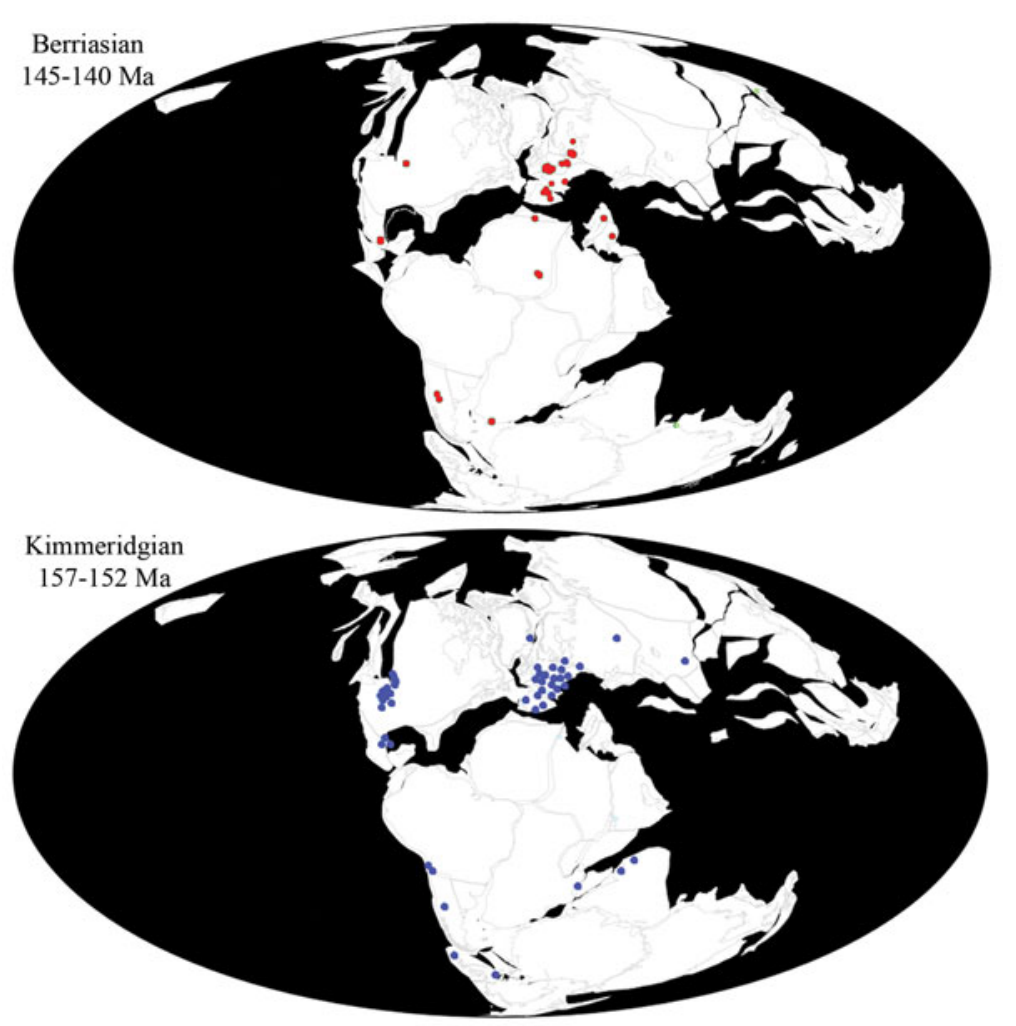

Imperial College London, 2016; Tennant et al. 2016), and eventually to the fragmentation of Gondwana (Li \& Powell, 2001; Stampfli \& Borel, 2002; Blakey, 2008). The Jurassic and Cretaceous vertebrate faunas evolved as a consequence of these tectonic events and changing geographic position of the continents.

Morocco is a key area for understanding the palaeobiogeographical history of vertebrates because of its geographic position on the African shores of the Tethys (Sigogneau-Russell et al. 1998; Gheerbrant \& Rage, 2006; Haddoumi et al. 2016), at a crossroad between Laurasia and Gondwana. A remarkably rich and diverse continental microvertebrate fauna, first described in the course of three field campaigns in 1983, 1986 and 1988, occurs in a lenticular calcareous sandstone near the village of Anoual and the Ksar Metlili fort (Sigogneau-Russell et al. 1998) in the High Atlas Mountains, eastern Morocco. This site, known as Ksar Metlili (previously also called the 'Anoual locality') belongs to the Ksar Metlili Formation (Haddoumi et al. 1998; Sigogneau-Russell et al. 1998) and was originally dated as Berriasian (earliest Cretaceous, $140 \mathrm{Ma}$ to $145 \mathrm{Ma}$ ) on the basis of calcareous nannofossils (Sigogneau-Russell et al. 1990). The vertebrate assemblage includes mammals, dinosaurs, pterosaurs, crocodylomorphs, turtles, squamates, rhynchocephalians, lissamphibians, lungfishes, coelacanths, actinopterygians and chondrichthyans (Duffin \& Sigogneau-Russell, 1993; Sigogneau-Russell et al. 1998). In 2010, an international expedition of French, Swiss and Moroccan researchers discovered new sites with microvertebrate accumulations in the Anoual Formation (Bathonian, Middle Jurassic) near the locality of Guelb el Ahmar (Haddoumi et al. 2016), and the original Ksar Metlili fossil locality was revisited. About 1.5 tons of sediments were sampled for screen-washing (Figs 2, 3) from several new loci of the Ksar Metlili locality. We describe here this new Ksar Metlili collection as well as that of the 1980s.

The Anoual Syncline is the only place in Africa that has yielded microvertebrate assemblages of Middle Jurassic and possibly earliest
Cretaceous age. From a palaeobiological perspective, it includes the two richest and most diversified faunas known in Africa and Gondwana for this period (Sigogneau-Russell et al. 1998; Haddoumi et al. 2016). These faunas are currently among the best-known representatives of the Mesozoic African palaeoecosystems. In addition, the Anoual Syncline records one of the few Jurassic-Cretaceous faunal successions in Gondwana (Haddoumi et al. 2016), if the Cretaceous age of the Ksar Metlili Formation is confirmed (see Section 6.c below). The aim of this paper is to update the faunal list of the Ksar Metlili fossil locality, to examine the diversity and the main taphonomic and palaeoenvironmental characteristics of this fossil assemblage, and to review the biostratigraphical and palaeobiogeographical significance of the fauna.

Abbreviations. CR2P - Centre for Research on Palaeontology, Paris, France; GEA - Guelb el Ahmar locality, Anoual Formation, Bathonian (Middle Jurassic), Anoual Syncline, Morocco; KM Ksar Metlili fossil locality, Ksar Metlili Formation, ?Berriasian (Lower Cretaceous), Anoual Syncline, Morocco (it corresponds to the fossil locality discovered in 1983 by D. Sigogneau-Russell's team (old collections, indicated by the prefixes MCM or SA and deposited at the National Museum of Natural History), including the new loci sampled in 2010 by our team (Fig. 3; new collections, indicated by the prefix KM and currently housed at the MNHN); they will be deposited at the Faculty of Sciences Ain Chock after study, with the prefix FSAC-KM); MNHN - National Museum of Natural History, Paris, France.

\section{Geological context}

The Ksar Metlili (KM) microvertebrate site, which forms the focus of this study, is situated in the 'Couches Rouges' ('Red Beds', or 'Continental Intercalaire'; Kilian, 1931) in the Moroccan eastern High Atlas Mountains, c. $12 \mathrm{~km}$ west of Anoual City, near the 

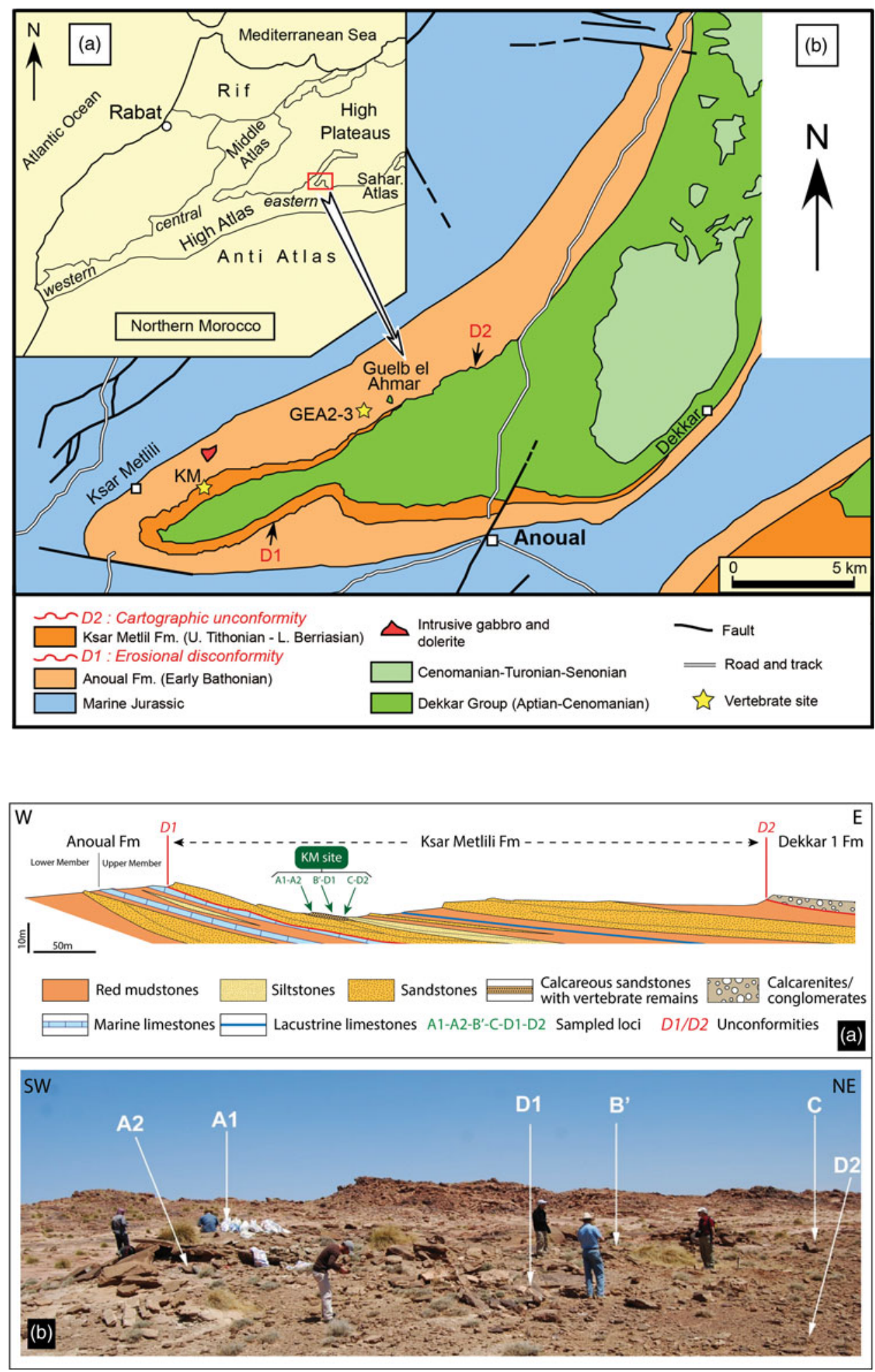

Fig. 2. (Colour online) Geographic and geological settings of the Anoual Syncline. (a) Location of the study area and (b) simplified geological map of the Anoual Syncline indicating the KM and GEA microvertebrate localities. Fm - Formation. Reprinted from Gondwana Research, vol. 29, Haddoumi et al. (2016), Guelb el Ahmar (Bathonian, Anoual Syncline, eastern Morocco): first continental flora and fauna including mammals from the Middle Jurassic of Africa, pp. 290319, Copyright (2016), with permission from Elsevier.
Ksar Metlili fort $\left(32^{\circ} 42^{\prime} 2^{\prime \prime} \mathrm{N}, 3^{\circ} 13^{\prime} 3^{\prime \prime} \mathrm{W}\right.$; Fig. 2). These 'Red Beds' are widely distributed in the Middle and High Atlas (Haddoumi et al. 2016).

\section{2.a. Stratigraphy and age of the Ksar Metlili site}

In the Anoual Syncline, Haddoumi et al. (1998, 2008) distinguished three Middle Jurassic-Cretaceous stratigraphical units in the 'Red Beds', which comprise from base to top: the Anoual Formation (lower Bathonian), the Ksar Metlili Formation (?Berriasian or upper Tithonian - lower Berriasian transition) and the Dekkar Group (?Barremian to Cenomanian). The Ksar Metlili Formation is delimited at its base by an erosional disconformity ('D1', Fig. 4) and at its top by a cartographic unconformity (the angle of unconformity is slight at the outcrop scale but is of regional scale and so easily recognized on a geological map; 
Fig. 4. (Colour online) Stratigraphic log and sequential evolution of the 'Red Beds' exposed in the Anoual Syncline, with indication of the stratigraphic position of the KM and GEA localities. Barr - Barremian; Fm - Formation. Modified from Haddoumi et al. (2008, Creative Commons BY-NC-SA 4.0).

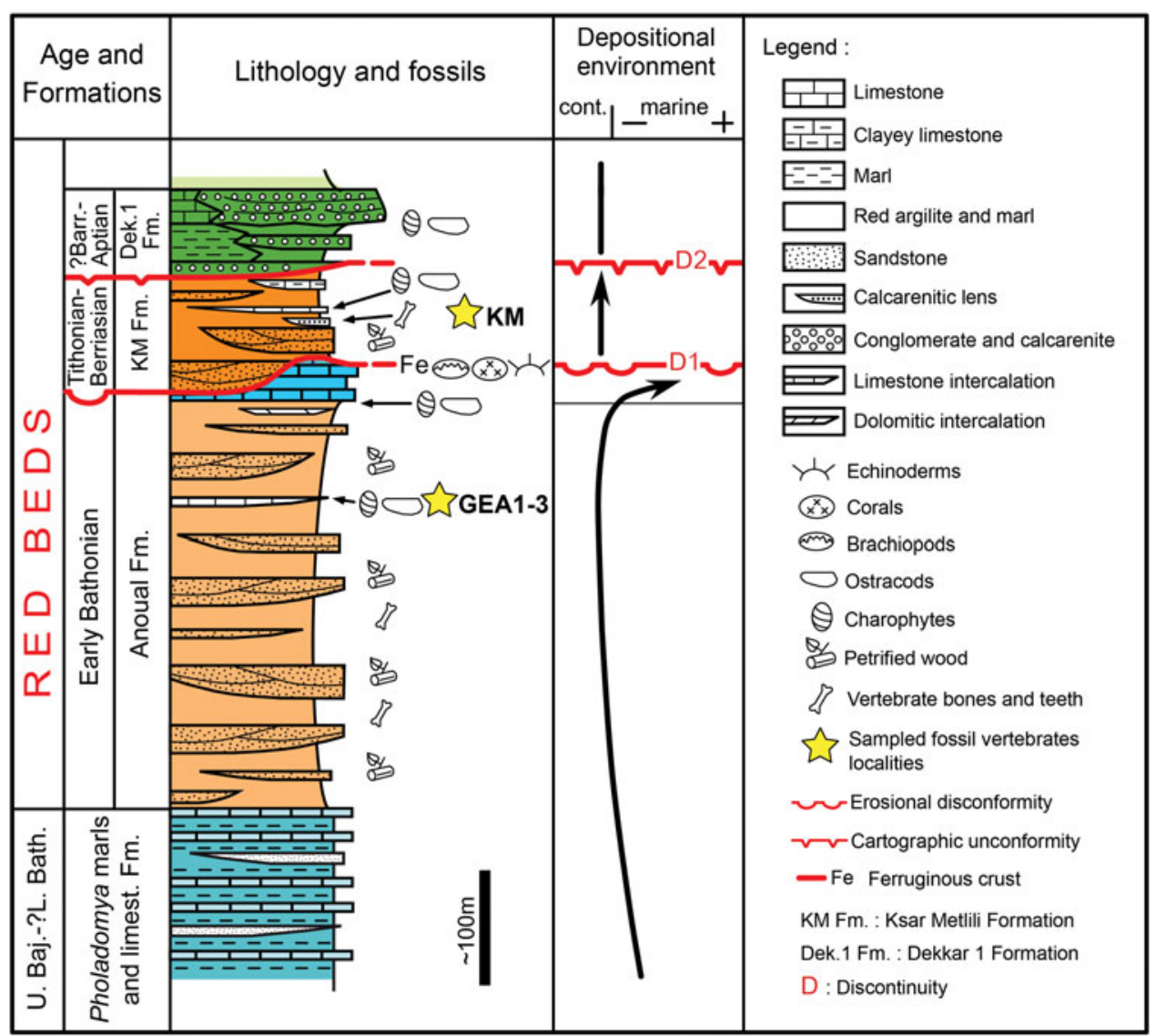

'D2', Fig. 4), constituting a lenticular bedded deposit of $c .80 \mathrm{~m}$ thickness (Haddoumi et al. 2008).

The age of the 'Couches Rouges' has long been debated because of the absence of reliable chronostratigraphic markers (Monbaron, 1988; Sigogneau-Russell et al. 1990; Haddoumi et al. 2016), but a Middle Jurassic to Early or early Late Cretaceous age is generally assigned to the strata (Sigogneau-Russell et al. 1990; Zouhri et al. 2017). However, opinions diverge about the temporal interpretation of this sequence. The 'Red Beds' containing the KM microvertebrate lens are a thick pelitic sandstone sequence that lies in stratigraphic conformity on the upper Bajocian - ?lower Bathonian marls and limestones (Pholadomya marls and limestones Formation, Fig. 4; Haddoumi et al. 2016). A few dozen metres above the microvertebrate-yielding lens, there are some slightly discordant conglomerates, but the same index minerals (micas, potash feldspars and kaolinite) are present below and above the discordance D2. This led Sigogneau-Russell et al. (1990) to exclude the presence of a major hiatus and to suggest that the sequence may be continuous from the Bathonian to the Cenomanian. However, given the involved time span (c. $68 \mathrm{Ma}$ ), continuous sedimentation (i.e. the absence of an important gap) would imply incredibly low sedimentation rates, which are unlikely in the geodynamic context. Haddoumi et al. (2008) recognized instead a major discontinuity (D1) between the Anoual and Ksar Metlili formations. In the south of the Anoual Syncline it is represented by a hardened surface, often ferruginous, which incises the marine upper member of the Anoual Formation (Fig. 4: D1). The Ksar Metlili Formation directly overlies the continental lower member of the Anoual Formation (Fig. 4) in several sections described by Haddoumi et al. (2008).
The original Berriasian age of the KM microvertebrate site was based on the discovery of calcareous nannofossils resembling the genera Polycostella (Tithonian-lower Berriasian), Micrantholithus (Berriasian-Aptian) and Nannoconus (upper Tithonian-Barremian) in a marly horizon located just below the microvertebrate-yielding lens (Sigogneau-Russell et al. 1990). The presence the selachian Egertonodus basanus at the KM fossil locality would also support this Berriasian age (Duffin \& Sigogneau-Russell, 1993). Gyrogonites of the Porocharaceae Porochara maxima have been identified 5 to $7 \mathrm{~m}$ above the KM lens (Haddoumi et al. 2008; Mojon et al. 2009). This species is restricted to the late Tithonian and early Berriasian period, thus suggesting that the top of the Ksar Metlili Formation was deposited during this interval. However, all those datings (calcareous nannofossils, charophytes and fauna) are based only on the presence of isolated species and not on faunal associations, which would give more reliable information on the Ksar Metlili Formation age, as was acknowledged by Sigogneau-Russell et al. (1990).

\section{2.b. Sedimentary facies}

The sedimentary facies of the Ksar Metlili Formation are similar to those of the continental lower beds of the Anoual Formation (fineto-medium-grained sandstones, overturned cross-stratifications, ripple marks, root traces; Haddoumi et al. 2008). The Ksar Metlili Formation was likely deposited in a river-dominated deltaic plain, close to the sea (Sigogneau-Russell et al. 1990, 1998; Haddoumi et al. 2008). All the vertebrate-bearing beds sampled in the various KM loci show this kind of transitional facies. The $\mathrm{KM}$ microvertebrate lens is intercalated between two marine 
horizons (Sigogneau-Russell et al. 1990, 1998). There is a mixing of continental (wood, mammals, dinosaurs, etc.), brackish (bivalves) and undisputedly marine (echinoderms, coral, brachiopods, etc.) forms in this horizon, which suggests a near-shore, deltaic depositional environment, probably influenced by eustatic variations (Sigogneau-Russell et al. 1990).

\section{Materials and methods}

The fossil microvertebrates reported here were discovered in a $0.2 \mathrm{~m}$ thick lenticular calcareous sandstone covering a surface of c. $200 \mathrm{~m}^{2}$; and was first sampled in the 1980s (Sigogneau-Russell et al. 1998; Jones et al. 2003; Fig. 4). In 2010 we resampled six fossiliferous loci, separated a few metres apart (KM-A1, KM-A2, KM-B', KM-C, KM-D1 and KM-D2; Fig. 3), in the same calcareous fossiliferous sandstone bed.

The KM faunal assemblage consists of microvertebrate fossil remains with a size range of 0.5 to $30 \mathrm{~mm}$, but most elements are millimetre sized. It includes the remains of various taxa, which have been disarticulated, fragmented and transported. It is dominated by isolated teeth and fish scales. This taphocoenosis provides a partial picture of the palaeocommunity. However, it has been demonstrated that such microvertebrate sites remain broadly representative of the local palaeobiodiversity (Rogers \& Brady, 2010; Cullen et al. 2016). By giving a general overview of it, such sites highlight the link between large-scale environmental and faunal changes, and they are important biochronological and palaeoenvironmental indicators (Rogers \& Brady, 2010; Cullen et al. 2016).

\section{3.a. Material}

Except for the pterosaur and dinosaur material (Knoll, 2000; Knoll \& Ruiz-Omeñaca, 2009), the original KM collections made by Sigogneau-Russell and colleagues in the 1980s (prefix MCM or SA) are housed at the MNHN. The new material collected in 2010, which comprises 24541 microvertebrate elements, will be housed, after study, at the Faculty of Sciences Aïn Chock, University Hassan II, Casablanca, Morocco (with the prefix FSAC-KM). Full details of specimen numbers are given in the online Supplementary Material Table S1.

\section{3.b. Specimen preparation}

The newly sampled blocks of calcareous sandstone containing the KM microremains were processed by acid attack, using $7 \%$ formic acid saturated with tricalcium phosphate. The lithoclastic and bioclastic sand recovered following this process was reconcentrated using hydrogen peroxide; size fractions were separated from each other using sieves of 5, 2, 1 and $0.5 \mathrm{~mm}$ mesh and then sorted under stereomicroscope.

The counting of the vertebrate microremains was made using the 'Count Image Elements' script specially developed by Auréliane Gailliègue (pers. comm. to ML, April 2017). It is based on the principle of picture segmentation: the elements are pictured on a white background; the script then analyses the picture and groups together the pixels with the same grey level. A grey level threshold value is calculated using the Otsu method (see Sezgin \& Sankur, 2004 for details) and defines two pixel categories: the pixels with a grey level above the threshold value (i.e. constituting the fossils) are attributed to one category; those with a grey level below this value (i.e. constituting the background) are attributed to the other. The number of pixel groups in the first category is the number of fossils. Thus, this script allows the counting of elements on the basis of the difference in contrast.

\section{Review of the Ksar Metlili fauna}

\section{4.a. Faunal list and palaeobiodiversity of the Ksar Metlili fauna}

The KM collections made by D. Sigogneau-Russell and colleagues in the 1980s have been presented in numerous publications (Sigogneau-Russell et al. 1988, 1990, 1998; Sigogneau-Russell, 1989, 1991a, 1991b, 1991c, 1992, 1995a, 1995b, 1999, 2003; Duffin \& Sigogneau-Russell, 1993; Sigogneau-Russell \& Ensom, 1994, 1998; Broschinski \& Sigogneau-Russell, 1996; Evans \& Sigogneau-Russell, 1997, 2001; Knoll, 2000; Gardner et al. 2003; Hahn \& Hahn, 2003; Jones et al. 2003; Knoll \& Ruiz-Omeñaca, 2009); these include the microvertebrate fauna from the 'Séquence B des Couches Rouges' of the Anoual Syncline (Sigogneau-Russell et al. 1990), now called the Ksar Metlili Formation (Haddoumi et al. 2008). Here we provide an updated taxonomic list of the KM microvertebrate fauna, based both on the old and new collections (Table 1).

The 1980s collections comprise 271 numbered specimens, belonging to at least 39 species, among which 22 were new and described for the first time: one selachian, one albanerpetontid, one caecilian, one anuran, one sphenodontian, one squamate and 16 mammals. The new collections contain 30 species (Tables 2,3). Considering the entire collection and shared species of both old and new collections, there are at least 47 vertebrate species in the KM fauna.

\section{4.b. Taxonomic composition of the Ksar Metlili fauna}

\section{4.b.1. Chondrichthyes}

In the KM fauna, the chondrichthyans are only represented by elasmobranchs. Two Hybodontiformes genera have been identified, Egertonodus basanus and Lonchidion marocensis (Duffin \& Sigogneau-Russell, 1993; Rees \& Underwood, 2002). The Valanginian-Aptian stratigraphic range of E. basanus (Biddle \& Landemaine, 1988; Duffin \& Sigogneau-Russell, 1993; Frederickson et al. 2018) would tend to confirm a Cretaceous age for the Ksar Metlili deposit, although it does not provide a full corroboration of the previously suggested Berriasian age (Duffin \& Sigogneau-Russell, 1993). Moreover, E. basanus could be a synonym of E. duffini, described from the middle Bathonian of Great Britain (Rees \& Underwood, 2008), so Egertonodus does not provide any precision on the biostratigraphic dating of the KM fossil locality.

\section{4.b.2. Actinopterygii}

Ginglymode actinopterygian remains are predominant in the $\mathrm{KM}$ limestones. Because of the incompleteness of the majority of the scales, it is difficult to make the distinction between Lepisosteiformes and Semionotiformes, and we thus assign the material to Ginglymodi indet. Pycnodontiformes, Osteoglossiformes and, tentatively, Cypriniformes are also identified (Duffin \& Sigogneau-Russell, 1993; Sigogneau-Russell et al. 1998). Some spine-shaped bones in the new material are reminiscent of pectoral or dorsal fin spines of Siluriformes (see Argyriou et al. 2015; Kovalchuk \& Ferraris, 2016; Vallone et al. 2017 for comparison material) or Polypteriformes (see Daget et al. 2001 and Gayet et al. 2002 for comparison). These are elongated and flat bones with one end larger than the other. This larger, proximal end bears a bulge with four processes that suggest articular facets, 
Table 1. Faunal list of the microvertebrates from the Ksar Metlili locality, Anoual Syncline, eastern Morocco, with details for each local sampled locus*

\begin{tabular}{|c|c|c|c|c|c|c|c|}
\hline & $\mathrm{KM}-\mathrm{A} 1$ & $\mathrm{KM}-\mathrm{A} 2$ & KM-B' & $\mathrm{KM}-\mathrm{C}$ & KM-D1 & KM-D2 & Original site (KM 1983) \\
\hline \multicolumn{8}{|l|}{ Chondrichthyes } \\
\hline \multicolumn{8}{|l|}{ Hybodontiformes } \\
\hline Egertonodus basanus & • & $\cdot$ & $\cdot$ & & $\cdot$ & & - \\
\hline \multicolumn{8}{|l|}{ Actinopterygii } \\
\hline Pycnodontiformes indet. & - & $\cdot$ & & & - & & - \\
\hline Osteoglossiformes indet. & - & & - & & & & - \\
\hline ?Cypriniformes indet. & & & & & & & - \\
\hline ?Siluriformes or ?Polypteriformes indet. & - & & $\cdot$ & & $\cdot$ & & \\
\hline cf. Mawsoniidae indet. & & $\cdot$ & & & & & \\
\hline \multicolumn{8}{|l|}{ Dipnoi } \\
\hline cf. Ptychoceratodontidae indet. & • & - & • & & - & • & - \\
\hline \multicolumn{8}{|l|}{ Lissamphibia } \\
\hline \multicolumn{8}{|l|}{ Albanerpetontidae } \\
\hline Anoualerpeton unicus & • & $\cdot$ & $\cdot$ & & & $\cdot$ & - \\
\hline \multicolumn{8}{|l|}{ Anura } \\
\hline aff. Enneabatrachus & & & & & & & - \\
\hline Aygroua anoualensis & & & & & & & - \\
\hline Choristodera indet. & • & & • & & • & • & \\
\hline \multicolumn{8}{|l|}{ Testudinata } \\
\hline \multicolumn{8}{|l|}{ Pleurodira } \\
\hline ?Araripemydidae indet. & & & & & & & - \\
\hline Cryptodira indet. & & & & & & & - \\
\hline Testudinata indet. & • & $\cdot$ & • & & • & $\cdot$ & \\
\hline \multicolumn{8}{|l|}{ Lepidosauromorpha } \\
\hline \multicolumn{8}{|l|}{ Sphenodontia } \\
\hline Tingitana anoualae & & & & & & & - \\
\hline Sphenodontia indet. ('Sphenodontia B') & & & & & & & • \\
\hline Sphenodontia indet. & • & & • & & & & \\
\hline \multicolumn{8}{|l|}{ Scincomorpha } \\
\hline Paramacellodus marocensis & & & & & & & - \\
\hline Scincomorpha indet. & & & • & & & & \\
\hline \multicolumn{8}{|l|}{ Squamata incertae sedis } \\
\hline Tarratosaurus anoualensis & & & & & & & - \\
\hline
\end{tabular}


Table 1. (Continued)

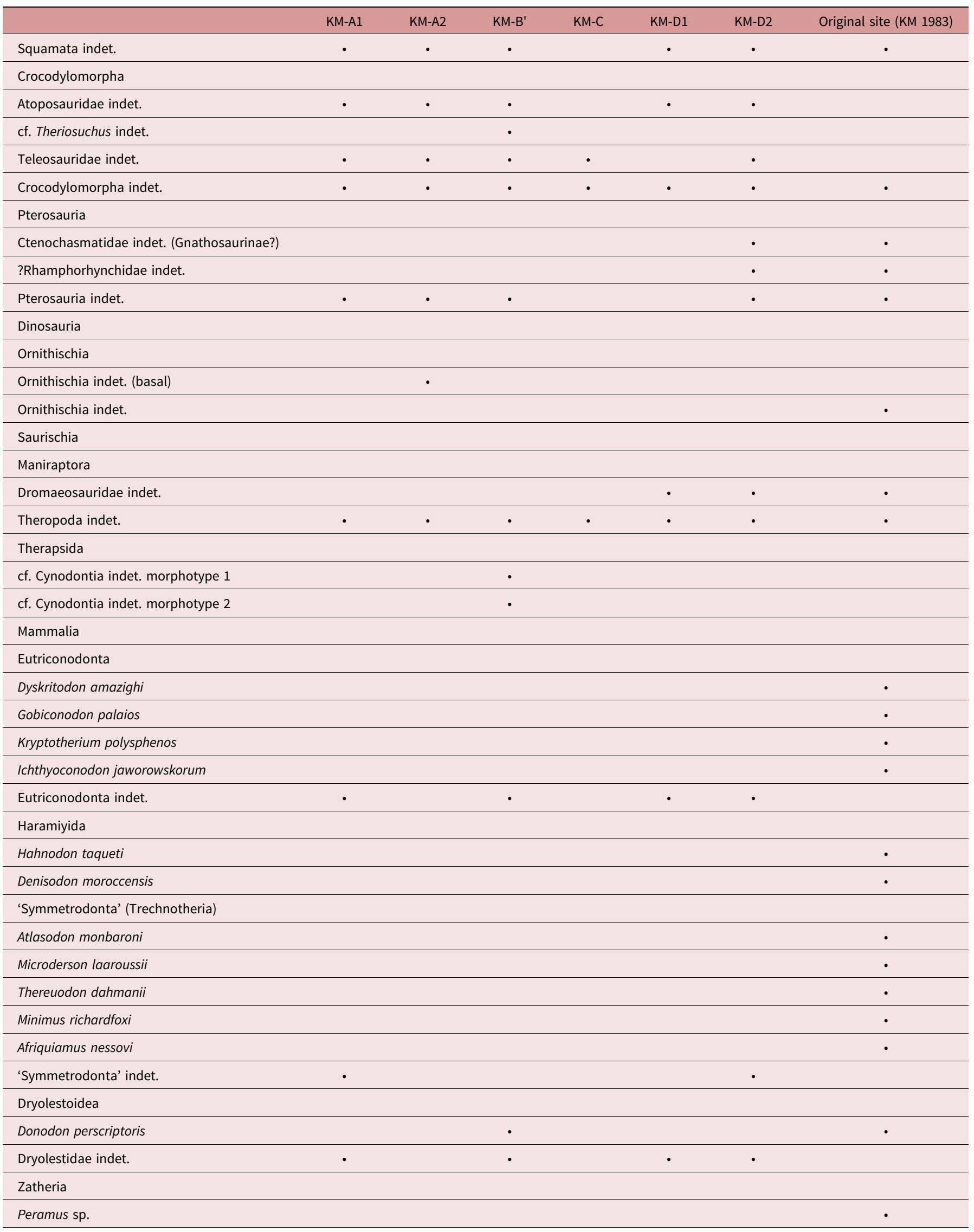


Table 1. (Continued)

\begin{tabular}{|c|c|c|c|c|c|c|c|}
\hline & KM-A1 & KM-A2 & KM-B' & $\mathrm{KM}-\mathrm{C}$ & KM-D1 & KM-D2 & Original site (KM 1983) \\
\hline Zatheria indet. & & & & & & & - \\
\hline \multicolumn{8}{|l|}{ Cladotheria indet. } \\
\hline Hypomylos phelizoni & & & - & & & & - \\
\hline Hypomylos micros & & & - & & & & - \\
\hline
\end{tabular}

*Taxa in grey are new with respect to the old collections and determinations.

Table 2. Minimum number of species of the microvertebrate taxa from the Ksar Metlili site

\begin{tabular}{lccc}
\hline Taxon & $\begin{array}{c}\text { Number of } \\
\text { species, } \\
\text { old collections }\end{array}$ & $\begin{array}{c}\text { Number of } \\
\text { species, } \\
\text { newlections }\end{array}$ & $\begin{array}{c}\text { Number of } \\
\text { species, } \\
\text { both collections }\end{array}$ \\
\hline Chondrichthyes & 2 & 2 & 2 \\
\hline Actinopterygii & 4 & 4 & 5 \\
\hline Sarcopterygii & 2 & 2 & 2 \\
\hline Amphibia & 4 & 2 & 5 \\
\hline Choristodera & 0 & 1 & 2 \\
\hline Testudinata & 2 & 1 & 4 \\
\hline Lepidosauromorpha & 4 & 2 & 8 \\
\hline Archosauromorpha & 5 & 8 & 2 \\
\hline ?Cynodontia & 0 & 2 & 16 \\
\hline Mammalia & 16 & 6 & \\
\hline
\end{tabular}

two on the dorsal face and two on the ventral face (Fig. 5). We tentatively assign them to ?Siluriformes or ?Polypteriformes. At present, the oldest fossil record of Siluriformes varies from 72 Ma (Gayet \& Meunier, 2003) to 88.6 Ma; Patterson, 1993; Gayet \& Otero, 1999). The earliest fossil occurrence of polypteriforms is Cenomanian (Gayet et al. 2002). Thus, if one of these attributions is confirmed, then we shift back the earliest fossil occurrence of one of these groups by 45 million years at least. Thin-sections of these bones are currently under histological study and could confirm or modify this assignment, as some features in the bone microstructure could be reminiscent of what can be seen in the Holostei.

\section{4.b.3. Sarcopterygii}

The 2010 material includes lungfish dental plates similar to the material referred to Ptychoceratodontidae in the old collections (Duffin \& Sigogneau-Russell, 1993; Sigogneau-Russell et al. 1998), and so probably belongs to the same family. It also includes an actinistian postparietal shield: its ornamentation, made of subcircular grooves and of antero-posteriorly oriented subparallel gutters (Fig. 6a), is typical of the Mawsoniidae (G. Clément, pers. comm. ML, March 2017). The notch observed in the lateral view of the external edge is probably the vestige of the otic canal (Fig. 6b). Thus, we refer this bone to cf. Mawsoniidae.

\section{4.b.4. Lissamphibia}

4.b.4.a. Albanerpetontidae (Fig. 7a, b). The presence of an albanerpetontid, Anoualerpeton unicus, both in old and new collections, has to be emphasized. New remains of this species (Fig. 7a, b) increase the available material for this only known Gondwanan representative of albanerpetontids (SigogneauRussell et al. 1998; Gardner et al. 2003). The genus is also present in the upper Bathonian of the Kirtlington Cement Quarry ('Kirtlington Mammal Bed', Forest Marble Formation), Great Britain, where it is represented by the species $A$. priscus (Gardner et al. 2003).

4.b.4.b. cf. Alytidae (Fig. 7c). The material collected in 2010 yielded 15 stegochordal, opisthocoelous vertebrae, wider than long, with short, robust and distally enlarged transverse processes that were unknown in the old collections and that we refer to cf. Alytidae (Holman, 2003; S. Bailon, pers. comm. to ML, November 2018; Fig. 7c); this identification must be considered provisional, because the anuran postcranial skeleton is always more uniform than the skull and because the material is fragmentary. Before the discovery of the KM fauna, alytids were unknown in Gondwana until the Late Cretaceous period of India (Prasad \& Rage, 1991). Consequently, the KM locality yields the oldest known Gondwanan alytids if the present identification is confirmed.

In the old collections, two other anuran species were discovered: the alytid aff. Enneabatrachus sp. and the pipioid or pelobatoid Aygroua anoualensis (Jones et al. 2003). A caecilian species, Rubricacaecilia monbaroni, was also recognized: it is the earliest Gondwanan caecilian record (Sigogneau-Russell et al. 1998; Evans \& Sigogneau-Russell, 2001).

\section{4.b.5. Choristodera}

Some robust vertebrae unknown in the old KM collections are found in the new material (Fig. 8): their centrum is amphicoelous or amphiplatyan, with an opened neurocentral suture and a distinct longitudinal ridge bordered laterally by longitudinal grooves on the floor of the neural canal, the cotyle rims are thick, and a slight ventral constriction gives them a coil form; all these characters are reminiscent of choristoderan reptiles (Evans, 1991; Averianov et al. 2006; Vullo et al. 2014; Haddoumi et al. 2016), so we assign them to this group, although this identification needs to be substantiated with additional material. These freshwater or amphibious diapsids are well known in Laurasia (Matsumoto et al. 2013), but up to now the first and only known Gondwanan choristoderes had been recovered from the Middle Jurassic of the Guelb el Ahmar locality, Morocco (Haddoumi 
Table 3. Vertebrate relative abundances in the different loci of the Ksar Metlili site (\% of total vertebrate microremains collected)

\begin{tabular}{|c|c|c|c|c|c|c|}
\hline Taxon & KM-A1 & KM-A2 & KM-B' & $\mathrm{KM}-\mathrm{C}$ & KM-D1 & KM-D2 \\
\hline Chondrichthyes & $1.18 \%$ & $0.74 \%$ & & & $0.25 \%$ & $0.10 \%$ \\
\hline \multicolumn{7}{|l|}{ Actinopterygii indet. } \\
\hline ?Siluriformes/?Polypteriformes & $0.05 \%$ & & $1.76 \%$ & & $0.37 \%$ & \\
\hline Osteoglossiformes & & & $0.16 \%$ & & & \\
\hline Actinistia & & $0.25 \%$ & & & & \\
\hline Dipnoi & $0.36 \%$ & $0.49 \%$ & $0.84 \%$ & & $0.25 \%$ & $0.31 \%$ \\
\hline Albanerpetontidae & $0.05 \%$ & $0.49 \%$ & $0.05 \%$ & & & $0.10 \%$ \\
\hline Anura & $1.75 \%$ & $1.97 \%$ & $0.95 \%$ & & $1.60 \%$ & \\
\hline Choristodera & $0.05 \%$ & & $0.24 \%$ & & $0.25 \%$ & $0.21 \%$ \\
\hline Atoposauridae & $19.82 \%$ & $40.39 \%$ & $56.88 \%$ & & $54.94 \%$ & $38.30 \%$ \\
\hline Crocodylomorpha indet. & $39.50 \%$ & $30.30 \%$ & $11.64 \%$ & $53.33 \%$ & $12.10 \%$ & $19.57 \%$ \\
\hline Thalattosuchia & $0.05 \%$ & $0.25 \%$ & $1.94 \%$ & $20.00 \%$ & & $0.31 \%$ \\
\hline Pterosauria & $9.68 \%$ & $16 \%$ & $3.63 \%$ & & & $22.26 \%$ \\
\hline Ornithischia & & $0.25 \%$ & & & & \\
\hline Theropoda & $1.34 \%$ & $1.48 \%$ & $0.71 \%$ & $3.33 \%$ & $2.35 \%$ & $1.97 \%$ \\
\hline cf. Cynodontia & & & $0.11 \%$ & & & \\
\hline
\end{tabular}

For actinopterygians and crocodylomorphs, only teeth were considered (see Section 6.a). The most abundant taxa are bolded.

et al. 2016). Thus, the KM specimens represent one of the few occurrences of choristoderes in Gondwana.

\section{4.b.6. Testudinata}

The turtles from the KM material are currently under study. Tentative identification of shell fragments suggests they could be represented by three taxa with a great deal of reservation: Chelonii indet., Pelomedusoides indet. and ?Araripemydidae indet. (cf. Taquetochelys sp.?; Gmira, 1995; Zouhri et al. 2017). The rest of the material is referred to as Pleurodira indet., Cryptodira indet. or Testudinata indet.

\section{4.b.7. Lepidosauromorpha}

The KM lepidosauromorphs are represented by sphenodontians and squamates. At least two different sphenodontians are present: Tingitana anoualae (Evans \& Sigogneau-Russell, 1997) and an unnamed but distinct taxon referred to as 'Sphenodontia B' by Evans \& Sigogneau-Russell (1997). They were considered as the first post-Jurassic record of the group in Africa (Evans \& Sigogneau-Russell, 1997; Zouhri et al. 2017), but the Berriasian age for the KM fauna is here reassessed as possibly Jurassic (see Section 6.c below).
Squamates are represented by scincomorphs, with the species Paramacellodus marocensis (Richter, 1994), and by an incertae sedis fossorial lizard, Tarratosaurus anoualensis (Broschinski \& Sigogneau-Russell, 1996).

\section{4.b.8. Crocodylomorpha}

At least two types of crocodylomorphs were reported in the old KM collections (Sigogneau-Russell et al. 1990, 1998), but they have never been identified or studied. The new material highlights four types of crocodylomorphs: cf. Theriosuchus, teleosaurids, atoposaurids and a robust-toothed undetermined form.

4.b.8.a. cf. Theriosuchus (Fig. 9a). Two fused premaxillae ornamented with subcircular grooves were recovered in the 2010 material (Fig. 9a). Given the small size of the premaxillary ascending process (Fig. 9a), we can suppose that the division of external nares was made essentially by the anterior nasal process, which is reminiscent of the genus Theriosuchus (T. pusillus and T. grandinaris; J. P. Tennant, pers. comm. to ML, May 2017); thus, we tentatively assign this specimen to cf. Theriosuchus (Tennant et al. 2016). 


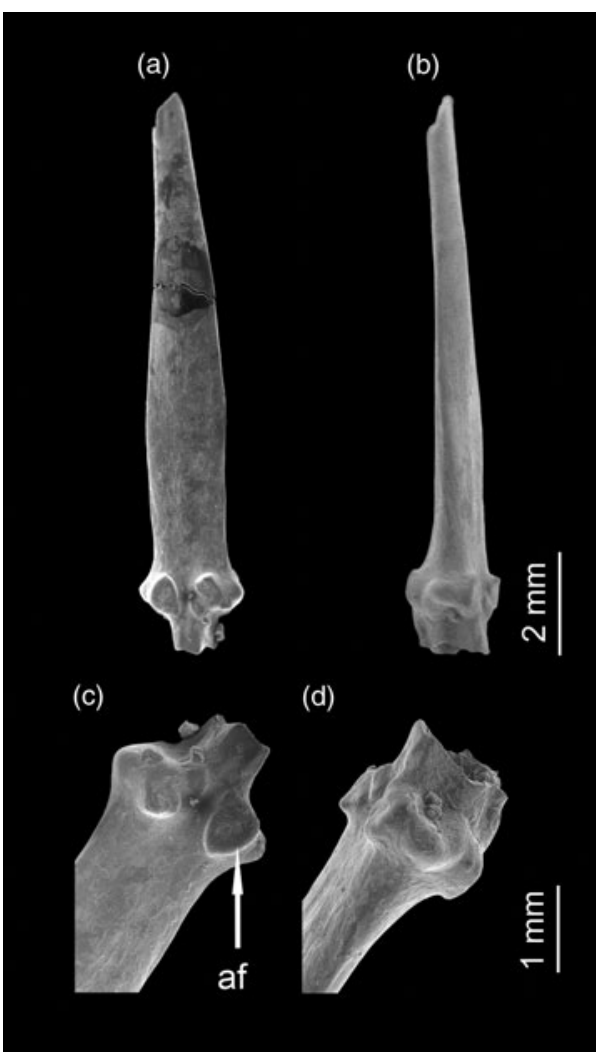

Fig. 5. Possible fin spine of ?Siluriformes or ?Polypteriformes indet. (KM-A1-40). (a) Dorsal view. (b) Ventral view. (c) Close-up on proximal end, dorsal view. (d) Close-up on proximal end, ventral view. af - articular facet (?).

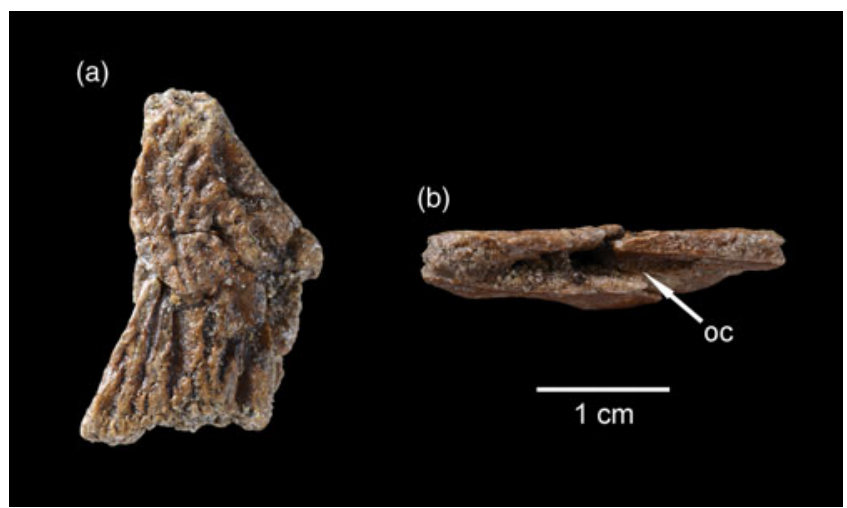

Fig. 6. (Colour online) Left postparietal shield of cf. Mawsoniidae indet. (KM-A2-11). (a) Dorsal view. (b) Left lateral view. oc - otic canal.

4.b.8.b. Teleosauridae (Fig. 9b). Teleosaurids are identified by slender, elongated, conical teeth, slightly recurved backwards and bearing numerous thin and regularly spaced longitudinal striae, converging towards the apex. They could be confused with caniniform teeth of atoposaurids, but within teleosaurids the tooth ornamentation is more pronounced, with higher ridges (Vignaud, 1997; Haddoumi et al. 2016), and overall the cross-section is subcircular, the crown is slightly compressed labiolingually but less than in atoposaurids, and carinae are weak to absent (Haddoumi et al. 2016), contrary to atoposaurid teeth (see, for example, Schwarz-Wings et al. 2009). The ratio between the longitudinal diameter of the crown base and the crown height is >3.5 (S. Jouve, pers. comm. to ML, May 2017; Vignaud, 1997; Fig. 9b). They closely resemble the teeth observed in teleosaurids such as Teleosaurus, Pelagosaurus and Steneosaurus (Vignaud, 1997; Pierce \& Benton, 2006) and to those identified as 'Teleosauridae indet.' in the GEA fauna (Haddoumi et al. 2016). These teleosaurid teeth could be related to the morphotype A3 described by Vignaud (1997).

4.b.8.c. Atoposauridae (Fig. 9c). Atoposaurids are identified by numerous lanceolate to leaf-shaped dental crowns, labiolingually compressed with a lingual concavity and both mesial and distal carinae; both lingual and labial faces bear thin vertical wrinkles diverging towards the carinae (Vullo et al. 2014; Fig. 9c). The teeth here described as belonging to atoposaurids are frequently assigned to Theriosuchus sp. in the case of Jurassic material (Vullo et al. 2014), even if an alternative attribution cannot be definitively rejected.

Atoposaurids and Theriosuchus are thought to be mostly, if not strictly, terrestrial crocodylomorphs, and their good representation in the KM fossil material points to a mostly terrestrial palaeoenvironment. It is worth noting that Theriosuchus is usually considered as an atoposaurid (Young et al. 2016), although for some authors this is a polyphyletic taxon that includes two groups of advanced neosuchians that would not belong to the Atoposauridae (Tennant et al. 2016).

Teleosaurids are, by contrast, strictly aquatic, and are often considered as purely marine reptiles (Bardet, 1995). However, some recent discoveries showed that some teleosaurids were able to live in freshwater (Martin et al. 2015); the KM specimens are among the first-known possible freshwater teleosaurids, and so constitute new evidence in favour of freshwater habitats for the family. Given the size of their teeth in the KM material they were probably young individuals (as for the GEA specimens; Haddoumi et al. 2016), which might suggest that they lived in a freshwater 'nursery' before moving to the sea (S. Jouve, pers. comm. to ML, May 2017).

All these crocodylomorph taxa are under study and will be described in a dedicated paper (ML Ph.D. work in progress).

\section{4.b.9. Pterosauria}

Two pterosaur groups can be recognized in the KM fauna (Knoll, 2000): one with slender, elongated teeth quite similar to those of ctenochasmatid pterosaurs such as Gnathosaurinae (Fig. 10a), and another with stronger and smoother teeth, reminiscent of the Ornithocheiridae (Fig. 10b), according to Knoll (2000). However, this second dental morphotype is also known within Rhamphorhynchidae (Averianov et al. 2005; Vullo et al. 2014), so the occurrence of Ornithocheiridae in the KM fauna cannot be confirmed without additional diagnostic material; furthermore, the small size (less than $20 \mathrm{~mm}$ ) and the possible Jurassic age we suggest here for the KM fauna would rather favour its assignment to ?Rhamphorhynchidae.

Though the KM ?Gnathosaurinae teeth represent one of the rare Cretaceous occurrences of the group (Knoll, 2000; Sweetman \& Martill, 2010), and they are among the latest representatives of this group while being the first discovered in Africa (Knoll, 2000), these results must be considered with caution, since their teeth are frequently confused with those of teleosaurid crocodylomorphs (see, for example, Buffetaut \& Jeffery, 2012), so a thorough revision of the KM pterosaur material is needed.

\section{4.b.10. Dinosauria}

4.b.10.a. Ornithischia (Fig. 11). Most of the dinosaur remains from the old KM collections are still undetermined and unstudied. Here, 

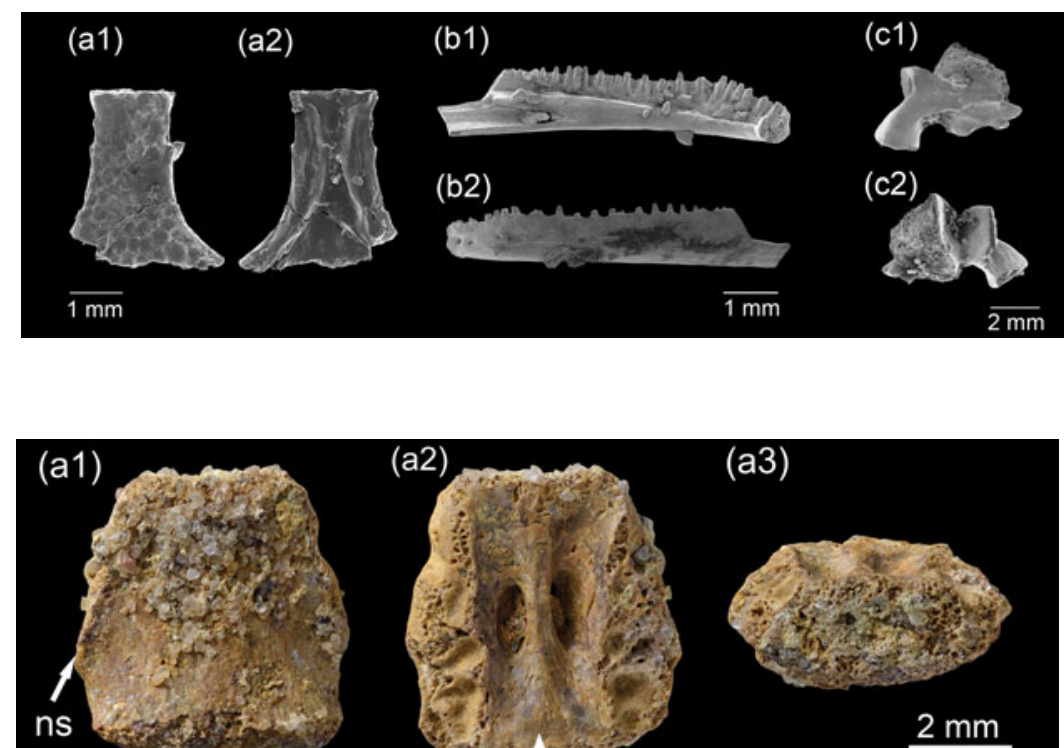

(a2)

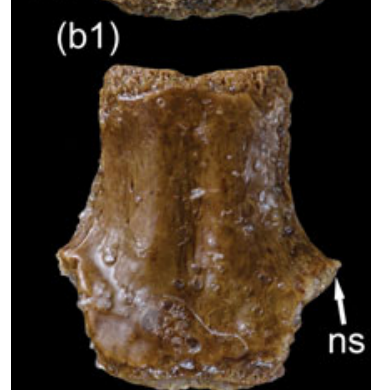

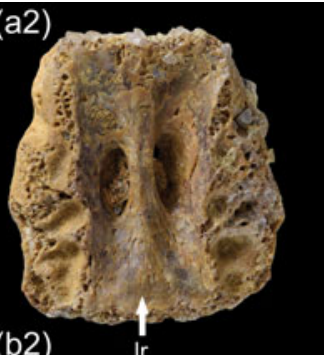

(b2)

\section{(a3)}

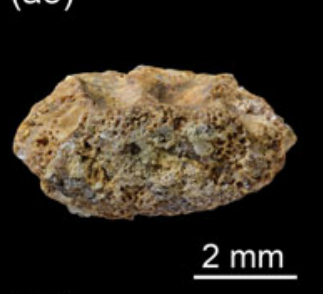

(b3)

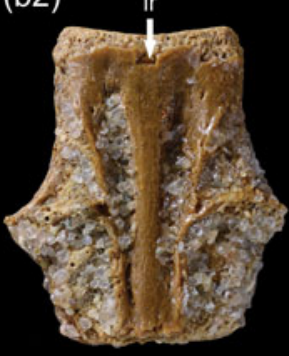

Fig. 7. Lissamphibians. (a) Fused frontals (A: KM-A2-7) of Anoualerpeton unicus in (a1) dorsal and (a2) ventral views. (b) Left dentary (B: KM-B'-12) of same in (b1) lingual and (b2) labial views. (c) Dorsal vertebra of cf. Alytidae indet. (KM-B'-18) in (c1) dorsal and (c2) ventral views.

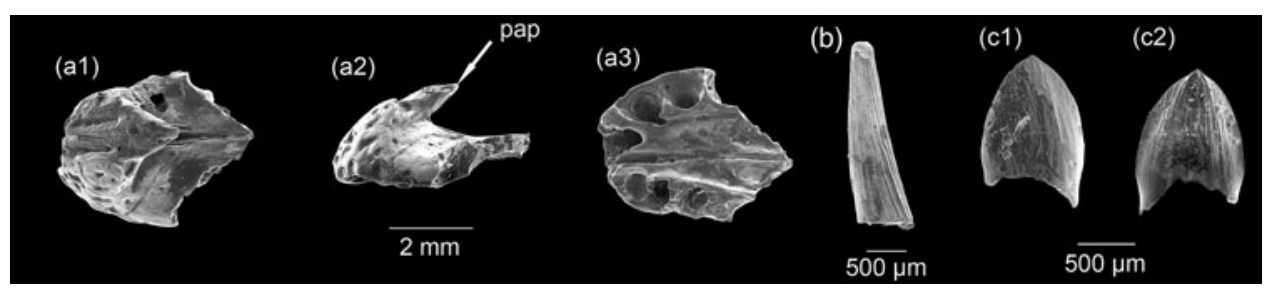

Fig. 9. Crocodylomorpha. (a) Fused premaxillaries of cf. Theriosuchus sp. indet. (KM-B'-42) in (a1) dorsal, (a2) left lateral and (a3) ventral views. (b) Tooth of Teleosauridae indet. (KMB'-53). (c) Tooth of Atoposauridae indet. (KM-C2 ) in (c1) labial and (c2) lingual views. pap - premaxillary ascending process.

we report the discovery in the 2010 material of a single ornithischian tooth (Fig. 11) that cannot be assigned to any known species and seems to represent a basal species of ornithischian, even if it is relatively young in geological age. The crown is slightly compressed laterally and shows a strong cingulum; it bears five well-developed cusps, aligned in the antero-posterior plane, with a central cusp about twice as high as the others; the lingual face of the crown is slightly concave; the root is unique, robust, and about one and a half times the size of the crown in height (Fig. 11). It is somewhat similar to the 'Ornithopoda basal indet. forme A' described by J. Pouech (unpub. Ph.D. thesis, Claude Bernard - Lyon 1 University, 2008) from the Berriasian of Cherves-de-Cognac (Charente, France). It can also be compared to a recently described neornithischian tooth from the Cenomanian of Utah (Avrahami et al. 2018). To a lesser degree, it also resembles the tooth from the Barremian of England attributed to an undetermined ornithischian or possibly referable to a heterodontosaurid by Sweetman (2016). This tooth from the KM fauna is also reminiscent of those described by Thulborn (1973) from the Kimmeridgian of
Portugal and referred to the hypsilophodontid Trimucrodon cuneatus (nomen dubium); however, in T. cuneatus, the mesialmost and distalmost denticles are salient and diverge away from the crown, which is not the case in the KM specimen. Further investigations are in progress, and this specimen will be described in a future publication (ML Ph.D. work in progress).

4.b.10.b. Theropoda. The theropods are only documented by teeth, and most of them are related to Theropoda indet., Maniraptoriformes indet. or Maniraptora indet. (Knoll \& Ruiz-Omeñaca, 2009). Knoll \& Ruiz-Omeñaca (2009) reported the presence of three Velociraptorinae morphotypes, but this should be considered cautiously owing to the difficulty in identifying a theropod subfamily from only isolated teeth (Hendrickx et al. 2015). A large part of these taxa could rather be related to Dromaeosauridae, which would be one of the earliest occurrences of this group, together with the teeth from the Upper Jurassic of Guimarota (Rauhut, 2000) and the specimens from the Barremian of China (Norell \& Makovicky, 2004). Isolated teeth tentatively attributed to dromaeosaurid-like theropods are reported from 
(a)

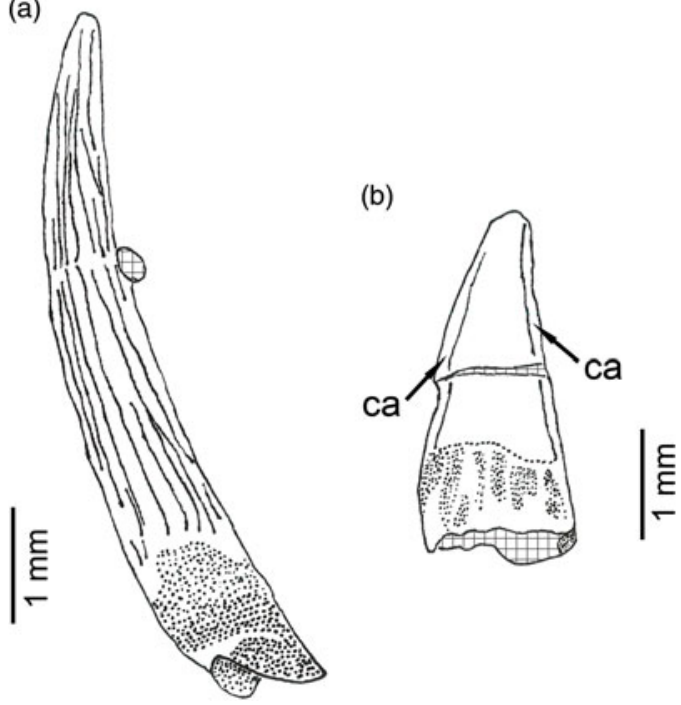

Fig. 10. Pterosauria. (a) Tooth of Ctenochasmatidae (?Gnathosaurinae) indet. (KMA2-21). (b) Tooth of ?Rhamphorhynchidae indet. (KM-A1-38). ca - carina.

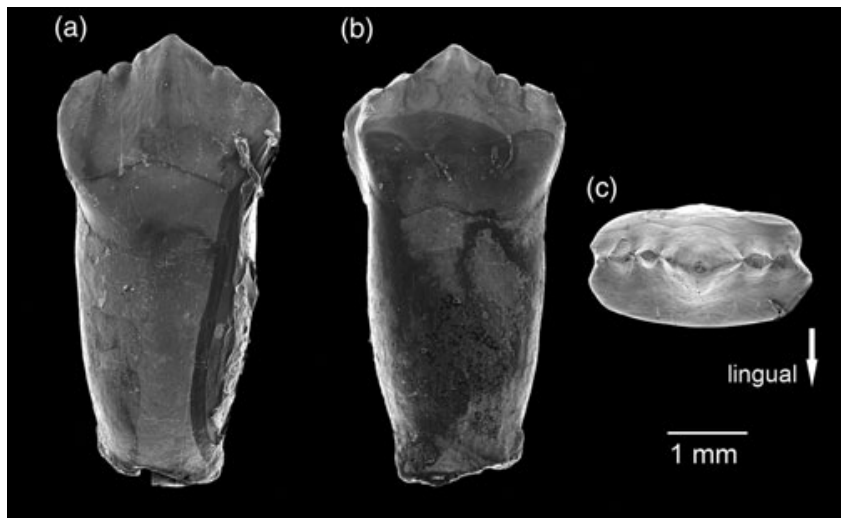

Fig. 11. Tooth of Ornithischia indet. (KM-A2-8). (a) Lingual view. (b) Labial view. (c) Occlusal view.

the Middle Jurassic of England (Metcalf et al. 1992), but their identification is uncertain and no fossil bones have been recovered from the Middle Jurassic so far. However, it is possible that those potential dromaeosaurid teeth from the KM fauna belong instead to Noasauridae or a basal tyrannosauroid (C. Hendrickx, pers. comm. to ML, March 2018). An in-depth revision of the KM theropod material, in progress, is beyond the scope of the present study.

\section{4.b.11. cf. Cynodontia}

Two tooth morphotypes that cannot be related to any of the identified major groups at Ksar Metlili were found in the new material collected in 2010 (Fig. 12; Lasseron, 2019). The first morphotype (Fig. 12a) consists of uniradiculate teeth with a slightly lingually curved and smooth crown, but some striae are observable on the labial face apex (Fig. 12a; see Lasseron, 2019 for details). The second dental morphotype (Fig. 12b) is broadly similar, but the lateral compression is not symmetrical (the labial face is more convex; Fig. 12b3) and there is no apical ridge (see Lasseron, 2019 for details).

These teeth are similar in morphology to single-rooted premolariform teeth of the small gobiconodontid BMNH M 45513 described by Sweetman (2006) from the Barremian of southern England (S. C. Sweetman, pers. comm. to ML, September 2018), and those of Gobiconodon borrisiaki from the Aptian-Albian of Mongolia (Kielan-Jaworowska \& Dashzeveg, 1998). However, they differ from both of them in several points (straight root, less clearly separated accessory cusps, presence of cingulum, etc. See Lasseron, 2019 for details). These teeth are also somewhat similar to those figured by Lucas \& Oakes (1988) and Godefroit \& Battail (1997) and identified as non-mammaliaform cynodonts (Pseudotriconodon, Gaumia). They are also similar to the tricuspid postcanine teeth of 'dromatheriids', such as Microconodon tenuirostris (Simpson, 1926; Sues et al. 1994; Sues, 2001), Rewaconodon tikiensis (Datta et al. 2004) and Polonodon woznikiensis (Sulej et al. 2018) from the lower Upper Triassic of the United States, India and Poland, respectively. Considering this 'dromatheriid' resemblance and the differentiation made by Datta et al. (2004) between the teeth of Rewaconodon, the KM specimens pictured in Figure 12a (KM-B'-44) and in Figure 12b (KM-?-1) may represent an anteriormost 'premolariform' and a posterior postcanine tooth, respectively. Thus, the KM specimens are tentatively referred to one or two species of non-mammaliform cynodonts (F. Abdala, pers. comm. to ML, September 2018). If their identification is confirmed, they would be among the last representatives of the non-mammaliaform cynodonts, along with the tritylodontids Montiricus kuwajimaensis from the Barremian/Aptian of Japan (Setoguchi et al. 1999; Matsuoka \& Setoguchi, 2000; Matsuoka et al. 2016), Xenocretosuchus sibiricus and X. kolossovi from the ?Valanginian-Hauterivian-Barremian and Barremian-Aptian of Russia, respectively (Tatarinov \& Mashchenko, 1999; Lopatin \& Agadjanian, 2008), and Stereognathus sp. from the Bathonian of Russia (Averianov et al. 2017). The detailed study of those possible cynodontian teeth will be published separately (Lasseron, 2019).

\section{4.b.12. Mammalia}

Mammals are remarkably diverse in the KM fauna. At least 16 species were identified in the old collections, and unpublished specimens belonging to new taxa remain to be described. Eutriconodontans are represented by Dyskritodon amazighi, Ichthyoconodon jaworowskorum (Sigogneau-Russell, 1995b), Gobiconodon palaios and Kryptotherium polysphenos (Sigogneau-Russell, 2003). SigogneauRussell (1995b) considered I. jaworowskorum and D. amazighi as semi-aquatic mammals. More recently, Gaetano \& Rougier (2011) referred I. jaworowskorum to the Volaticotherini, which are gliding mammals. Allotherians are represented by two species, Hahnodon taqueti (Sigogneau-Russell, 1991b; Hahn \& Hahn, 2003) and Denisodon moroccensis (Hahn \& Hahn, 2003), which are referred to the family Hahnodontidae. Recently Huttenlocker et al. (2018) showed that the Hahnodontidae does not belong to the Multituberculata but to the Haramiyida. Five species of 'Symmetrodonta' (Trechnotheria) are present: Atlasodon monbaroni, Microderson laaroussii (Sigogneau-Russell, 1991a), Thereuodon dahmanii (Sigogneau-Russell, 1989; Sigogneau-Russell \& Ensom, 1998; the holotype of this species has also been regarded as a deciduous posterior upper premolar of a holotherian, possibly zatherian, see Martin, 2002), Minimus richardfoxi and Afriquiamus nessovi (Sigogneau-Russell, 1999). The dryolestoids are the most frequently found among the mammal material in the KM fauna, and they are represented by at least one species, Donodon perscriptoris (Sigogneau-Russell, 1991a). In addition, one species of 'peramurid' is present, Peramus sp. (Sigogneau-Russell, 1999). Finally, three stem boreosphenidan (tribosphenidans) species have been described by 


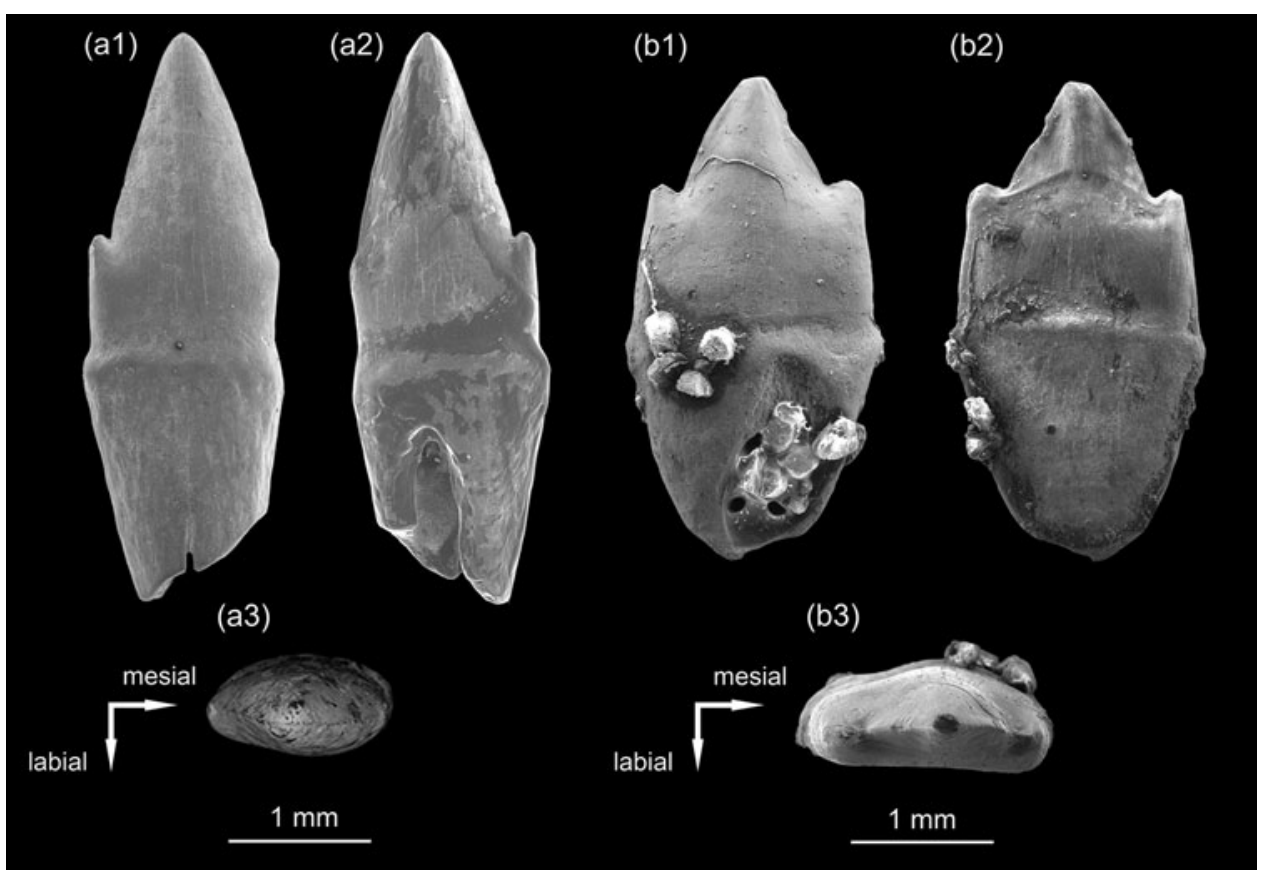

Fig. 12. cf. Cynodontia. (a) Tooth of morphotype 1 (KM-B'44) in (a1) labial, (a2) lingual and (a3) occlusal views. (b) Tooth of morphotype 2 (KM-?-1) in (b1) labial, (b2) lingual and (b3) occlusal views.

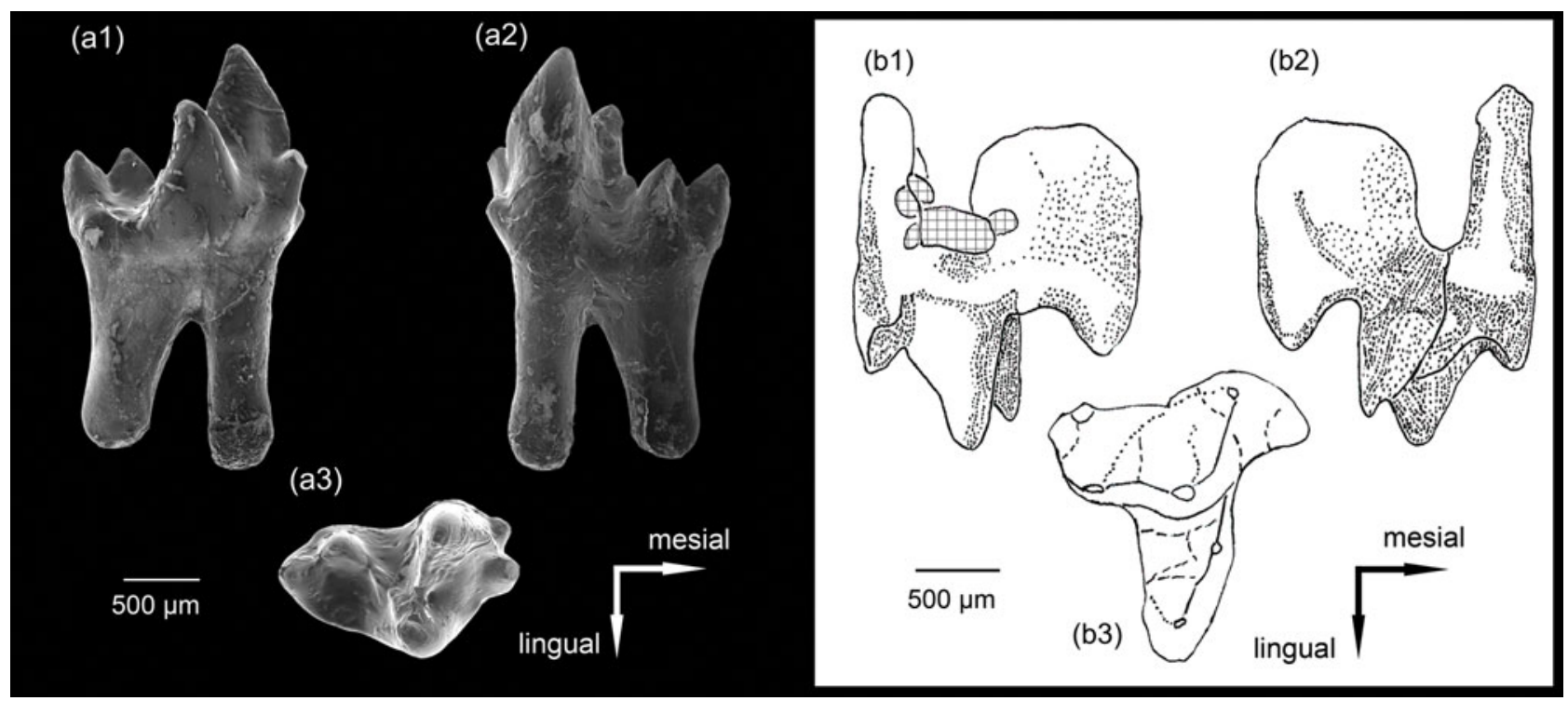

Fig. 13. Stem boreosphenidan mammals. (a) Left lower molar of Hypomylos phelizoni (KM-B'-4) in (a1) lingual, (a2) labial and (a3) occlusal views. (b) Right upper molar of Tribotherium africanum (KM-B'-5) in (b1) mesial, (b2) distal and (b3) occlusal views.

Sigogneau-Russell: Hypomylos phelizoni (Sigogneau-Russell, 1992, 1995a; Fig. 13a), H. micros (Sigogneau-Russell, 1995a) and Tribotherium africanum (Sigogneau-Russell, 1991c, 1995a; Fig. 13b). They are among the oldest known stem boresophenidan mammals and the first documented in Africa. Only four species of mammals, already described in the old collections, have been identified in the KM material collected in 2010: the dryolestoid D. perscriptoris, and the three stem boreosphenidans H. phelizoni (Fig. 13a), H. micros and T. africanum (Fig. 13b).

\section{Quantitative analysis of the Ksar Metlili fauna}

The number of identified taxa is broadly stable among the KM sites (Fig. 14; Table 1), with the notable exception of locality $\mathrm{C}$, where only four taxa can be recognized with certainty (Figs 3, 14). However, this is not significant as locality $\mathrm{C}$ is much less sampled: only $81 \mathrm{~kg}$ of rocks were sampled there, versus $675 \mathrm{~kg}$ for A1, for example (12\%; Table 3$)$.

The fossil material from Ksar Metlili collected in 2010 has been subject to a quantitative analysis to determine the relative 


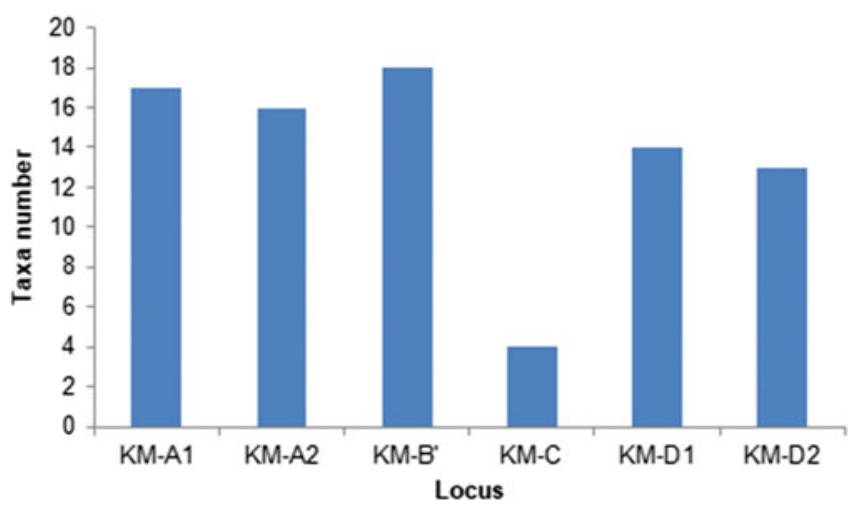

Fig. 14. (Colour online) Identified species number in each locus of the Ksar Metlili site, based on the 2010 sampled material.

abundance of each taxon, in order to detect a possible taphonomic bias or a size sorting. This analysis was carried out on the raw data from the element counting (Minimum Number of Elements, $\mathrm{MNE}$ ). However, it was impossible to reliably determine a Minimum Number of Individuals (MNI) from actinopterygian scales or teeth, archosaur teeth and turtle plates. Thus, it was considered preferable to limit the study to the MNE, in order to understand the overall structure of the vertebrate assemblage. We recovered 24541 fossil specimens from the 1.5 tons of matrix collected from six different loci, and we identified 30 species. We have also examined the distribution disparities of the main taxa identified in the different localities (Table 3).

From the raw data from the 2010 material, it is apparent that the fauna is widely dominated by actinopterygians, representing more than $71 \%$ of the elements, including a majority of ginglymodians (Fig. 15). Atoposaurids and other crocodylomorphs (except teleosaurids) represent $21 \%$ of the fossils recovered in the KM fauna, and pterosaurs and turtles $2.5 \%$ and $1.6 \%$, respectively (Fig. 15).

\section{Discussion}

\section{6.a. Faunal composition analysis and diversity: palaeoecological implications}

Microvertebrate accumulations record a wide variety of taxa and provide important palaeoecological data that complement data from macroremain localities (Jamniczky et al. 2008). They provide a general overview of the local palaeobiodiversity and are important palaeoenvironmental indicators of great use for palaeoecological reconstructions (Estes \& Berberian, 1970; Brinkman, 1990; Brinkman et al. 2004; Vullo, 2007; Rogers \& Brady, 2010; Cullen et al. 2016).

The noticeably higher frequency of fishes in (micro-)vertebrate assemblages ( $71 \%$ in the KM fauna) has been interpreted to be the result of mass mortality events, probably monotaxic or with a few taxa (Wenz \& Poyato-Ariza, 1994; Martill et al. 2008), which could be linked to anoxia, algal blooms or seasonal drought phenomenon (Martill et al. 2008). The last hypothesis is the most consistent with the sedimentary context of the KM locality. This high frequency can also be due to the large number of bones released when a fish skeleton gets disarticulated (teeth, scales, spines, vertebrae, etc.). The proportion of crocodylomorphs in the KM fauna $(21 \%)$ is consistent with the frequency of crocodylomorphs usually observed in localities yielding microremains (Sankey, 2008).

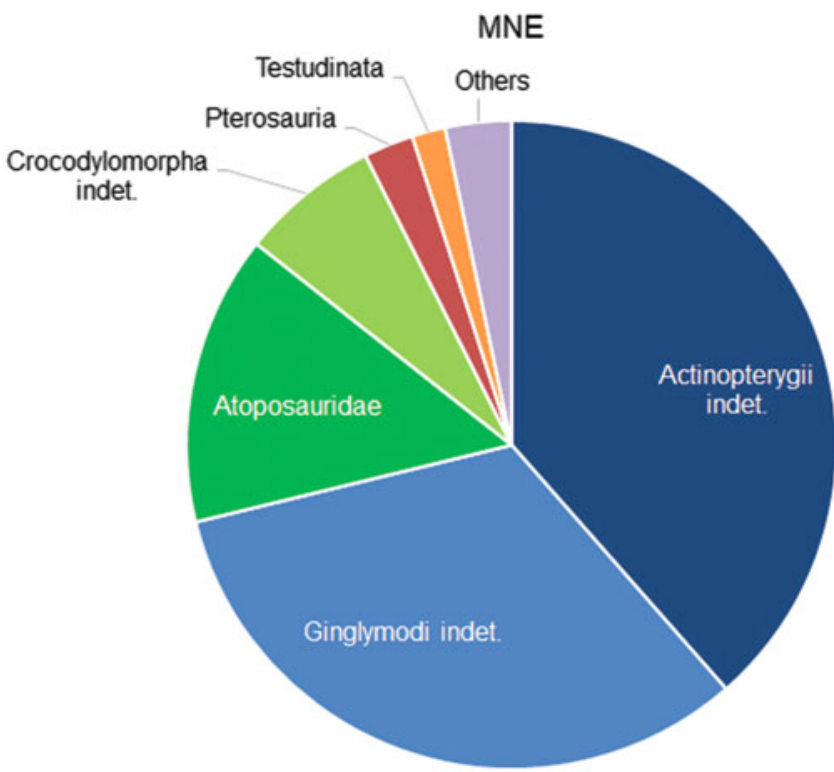

MNE (teeth)

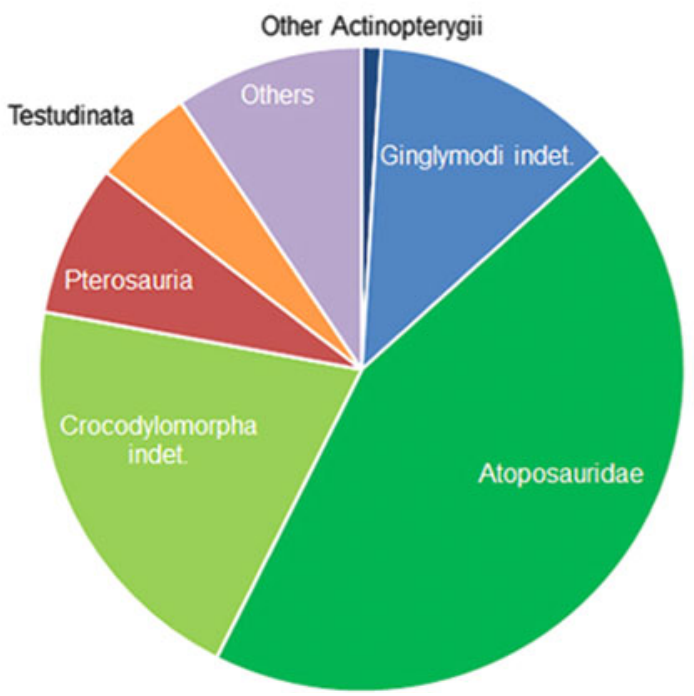

Fig. 15. (Colour online) Relative abundances of the Ksar Metlili taxa, based on the 2010 sampled material, considering all the elements or only teeth for actinopterygians and crocodylomorphs. Others = Vertebrata indet., Chondrichthyes, Pycnodontiformes, Osteoglossiformes, ?Siluriformes or Polypteriformes, Actinistia, Dipnoi, Tetrapoda indet., Albanerpetontidae, Anura, cf. Choristodera, Squamata, Rhynchocephalia, Teleosauridae, Ornithischia, Theropoda, ?Cynodontia, Mammalia.

Finally, four major groups - actinopterygians, crocodylomorphs, pterosaurs and turtles - represent more than $95 \%$ of the vertebrate remains found in the KM fauna, and this assemblage appears to be autochthonous or sub-autochthonous, because the lifestyle of these taxa is consistent with the river-dominated deltaic environment of the KM locality, i.e. they were probably permanent inhabitants of the local biotope. The presence of pterosaurs (2.5\%) in this major KM faunal association dominated by aquatic taxa could be the result of a trophic relationship: it seems reasonable to assume that pterosaurs were feeding on bony fishes and/or that some of them were eaten by crocodylomorphs. Fish-eating behaviour has been frequently reported for pterosaurs, based on their dental 

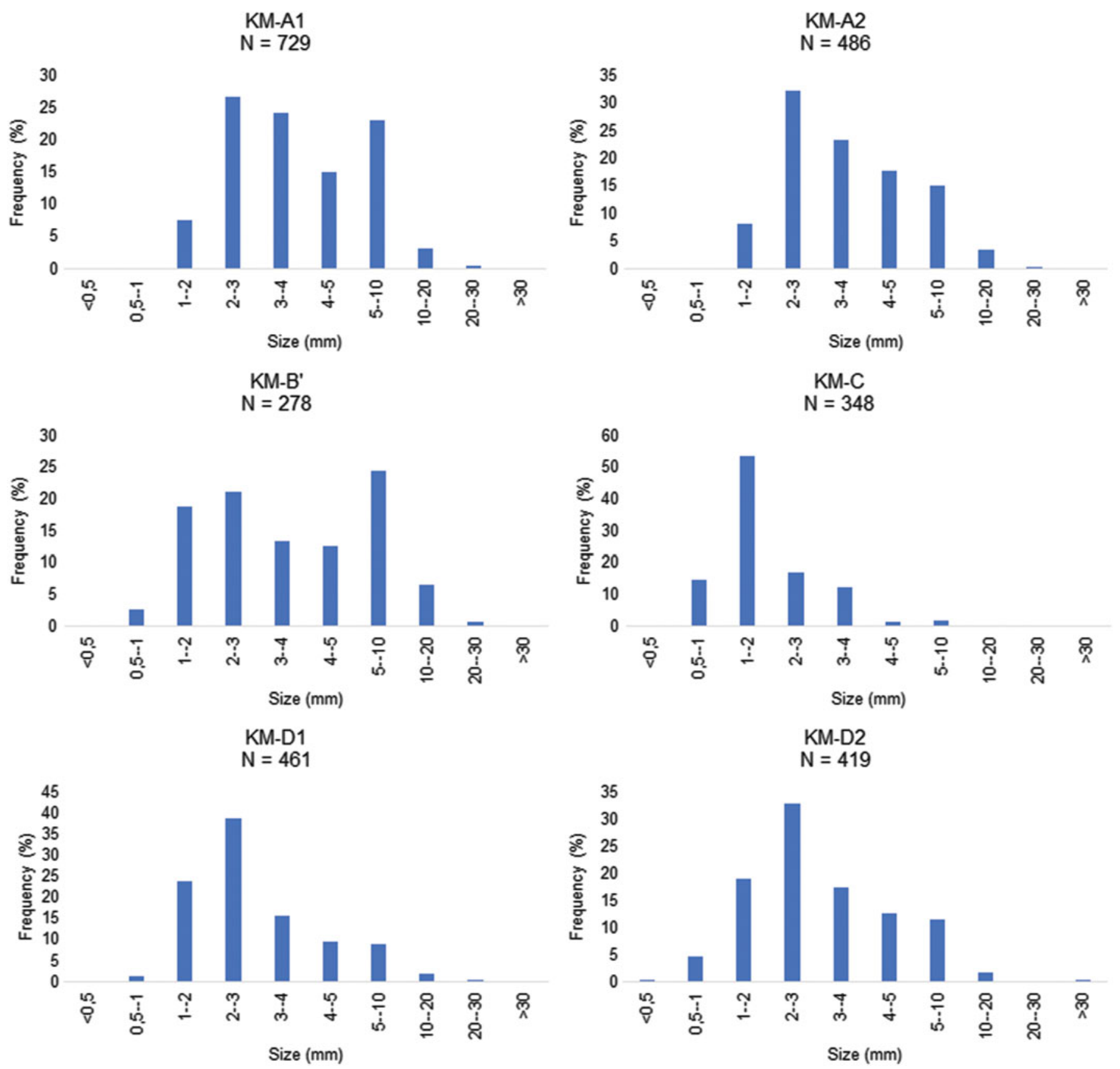

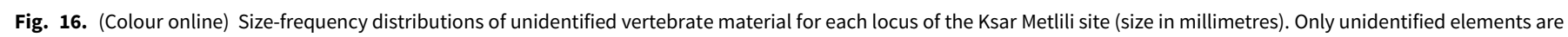
used here, in order to avoid the taxonomic bias due to variation in taxonomic composition in the different loci (see Section 6.b).

morphology or their gut content (Witton, 2013, 2018). Rhamphorhynchidae (or Ornithocheiridae, see pterosaur systematics in Section 4.b.9 above) are sometimes thought to use skimfeeding, pushing their lower jaw tip through the water to snap up food upon impact (Nessov, 1984); even if this hypothesis has been recently discounted (see Humphries et al. 2007; M. P. Witton, unpub. Ph.D. thesis, Univ. Portsmouth, 2008; Witton, 2013), several anatomical features support dip-feeding, in which the animal gleans food from the water's surface like terns and frigate birds (Unwin, 1988, 2005; Veldmeijer et al. 2006; Witton, 2013). Some Ctenochasmatoidea, such as Gnathosaurus and other Gnathosaurinae, could have a feeding behaviour similar to that of modern spoonbills, because of their spatulate jaw and dental profile, snatching small fishes and other swimming animals from the water column (Swennen \& Yu, 2004; Witton, 2013). The low abundance of the other taxa can be explained by different reasons: shed teeth for dinosaurs; the fragility of amphibian, lepidosaurian and mammal small bones; the cartilaginous skeleton of chondrichthyans and lungfishes (lungfishes are really scarce in the KM fauna, in contrast to the GEA fauna where their dental plates are frequent among the macroremains); different habitats; more transported remains, etc.

Actinopterygians are over-represented in the KM material, because of the large number of scales. This can be explained by the accumulation of individuals, the large number of preserved scales per individual and their robustness, which is characteristic 
of the Anoual sites. In order to correct this bias and to get as close as possible to the MNI, a second analysis was developed, considering only their teeth (Fig. 15). In the same way, we also did not count the crocodylomorph osteoderms. In this analysis, actinopterygians only represent $13 \%$ of the fauna, and the fauna appears dominated instead by crocodylomorphs, including atoposaurids (65\%), followed by pterosaurs ( $8 \%$ ) and turtles (5\%), as in the first analysis. Even if this correction still does not represent an exact picture of the palaeobiocoenosis, these results are consistent with the depositional environment of the KM locality. A similar pattern of relative abundances is found in all the KM sampled loci, suggesting the depositional environment and the faunal composition are broadly homogeneous in all the loci.

\section{6.b. Taphonomy and representativeness of the identified faunal diversity}

In order to establish comparisons of the taphonomic characters of the different studied sites, an analysis of fossil size-frequency distribution in the KM assemblage is essential (Blob \& Fiorillo, 1996; Brinkman et al. 2004; Vullo, 2007). Blob \& Fiorillo (1996) showed that this distribution may vary considerably between sites, even if they have identical sedimentological characteristics, because of the taxonomic composition. Thus, in order to reduce this taxonomic bias, only undetermined fossil remains have to be included in the analysis (Blob \& Fiorillo, 1996; Brinkman et al. 2004; Vullo, 2007). If microvertebrate assemblages have similar size distributions, the taphonomic explanation for faunal differences can be rejected (Blob \& Fiorillo, 1996; Brinkman et al. 2004), and the taxonomic composition of the assemblages can be properly compared (in terms of relative abundances of taxa).

For each locality, the measurements of maximum length were made on a set of randomly drawn fossils ( $\mathrm{n}=278$ to 729 ) (Fig. 16) devoid of any fresh breaks linked with the collecting or sorting process (see online Supplementary Material Table S2 for details). To test whether the size difference was significant and thus the similarity of the size-frequency distributions, non-parametric Kolmogorov-Smirnov tests were applied in the comparison of the size-frequency distributions (Brinkman et al. 2004). The null hypothesis (the observed differences among the sites are not significant, and so the sites are not significantly different) cannot be rejected at the 0.05 threshold (online Supplementary Material Table S3). Thus, faunal differences may have a biological basis, rather than a taphonomic one.

These patterns of size-frequency distribution show that there is no sorting of the fossils due to the element size, i.e. there is no major granulometric bias in the representation of the microfauna between the different sampled loci. However, it appears that the most delicate taxa (lissamphibians, squamates, pterosaurs and mammals) are preserved in greater quantities in A2 and D2 (Table 3), suggesting a low-energy depositional environment. This observation is consistent with the fine and well-sorted granulometry of the associated sedimentary particles (lithoclasts) from the respective localities. The sedimentary facies and environment of all loci, corresponding to a local fluvial channel deposit, is actually similar and the preservational differences only reflect local hydrodynamic differences in the same channel: the bioclastic elements are not concentrated and sorted in the same way at the bottom or at the edge of the channel.
Table 4. Faunal list of the Guelb el Ahmar site (Bathonian, Middle Jurassic), compared with the Ksar Metlili microvertebrate fauna

\begin{tabular}{lcc}
\hline & $\begin{array}{c}\text { Guelb el Ahmar } \\
\text { (Anoual Formation) }\end{array}$ & $\begin{array}{c}\text { Ksar Metlili (Ksar } \\
\text { Metlili Formation) }\end{array}$ \\
\hline Chondrichthyes & & \\
\hline
\end{tabular}

\section{Hybodontiformes}

Lonchidion (Lissodus)
marocensis

\begin{tabular}{l}
\hline Egertonodus basanus \\
\hline Actinopterygii
\end{tabular}

Actinopterygii

Ginglymodi indet. • •

\begin{tabular}{|c|c|c|}
\hline Pycnodontiformes indet. & & - \\
\hline Osteoglossiformes indet. & • & - \\
\hline ?Cypriniformes indet. & & - \\
\hline $\begin{array}{l}\text { ?Siluriformes or } \\
\text { Polypteriformes indet. }\end{array}$ & & - \\
\hline cf. lonoscopiforrmes indet. & - & \\
\hline \multicolumn{3}{|l|}{ Sarcopterygii } \\
\hline \multicolumn{3}{|l|}{ Actinistia } \\
\hline Actinistia indet. & & • \\
\hline cf. Mawsoniidae indet. & - & • \\
\hline \multicolumn{3}{|l|}{ Dipnoi } \\
\hline $\begin{array}{l}\text { cf. Ptychoceratodontidae } \\
\text { indet. }\end{array}$ & & - \\
\hline
\end{tabular}

\begin{tabular}{l}
\hline Arganodus sp. \\
\hline Albanerpetontidae \\
\hline
\end{tabular}

\begin{tabular}{l} 
Anoualerpeton unicus \\
Albanerpetontidae indet. \\
\hline Caudata \\
Caudata indet. \\
Anura
\end{tabular}

Anura

\begin{tabular}{ll} 
aff. Enneabatrachus & $\bullet$ \\
\hline Aygroua anoualensis & $\bullet$ \\
\hline cf. Alytidae indet. & $\bullet$ \\
\hline Anura indet. & $\bullet$ \\
\hline Gymnophiona
\end{tabular}

\begin{tabular}{l} 
Gymnophiona \\
Rubricacaecilia monbaroni \\
Diapsida incertae sedis \\
Choristodera indet. \\
Testudinata \\
Pleurodira \\
?Araripemydidae indet. \\
Cryptodira indet. \\
Testudinata indet. \\
Lepidosauromorpha \\
Sphenodontia \\
\hline Tingitana anoualae
\end{tabular}

(Continued) 
Table 4. (Continued)

\begin{tabular}{|c|c|c|}
\hline & $\begin{array}{c}\text { Guelb el Ahmar } \\
\text { (Anoual Formation) }\end{array}$ & $\begin{array}{l}\text { Ksar Metlili (Ksar } \\
\text { Metlili Formation) }\end{array}$ \\
\hline $\begin{array}{l}\text { Sphenodontia indet. } \\
\text { ('Sphenodontia B') }\end{array}$ & & - \\
\hline Sphenodontia indet. & $\cdot$ & $\bullet$ \\
\hline \multicolumn{3}{|l|}{ Scincomorpha } \\
\hline Paramacellodus marocensis & & • \\
\hline Scincomorpha indet. & • & • \\
\hline \multicolumn{3}{|l|}{ Squamata incertae sedis } \\
\hline Tarratosaurus anoualensis & & • \\
\hline \multicolumn{3}{|l|}{ Anguimorpha } \\
\hline cf. Parviraptor & - & \\
\hline Squamata indet. & - & - \\
\hline \multicolumn{3}{|l|}{ Crocodylomorpha } \\
\hline Atoposauridae indet. & • & • \\
\hline cf. Theriosuchus indet. & & - \\
\hline Teleosauridae indet. & - & - \\
\hline ?Metriorhynchidae indet. & - & \\
\hline Crocodylomorpha indet. & - & - \\
\hline \multicolumn{3}{|l|}{ Pterosauria } \\
\hline $\begin{array}{l}\text { Ctenochasmatidae indet. } \\
\text { (Gnathosaurinae ?) }\end{array}$ & & - \\
\hline Rhamphorhynchidae indet. & - & - \\
\hline Pterosauria indet. & - & \\
\hline \multicolumn{3}{|l|}{ Dinosauria } \\
\hline \multicolumn{3}{|l|}{ Ornithischia } \\
\hline cf. Stegosauria indet. & - & \\
\hline Ornithischia indet. (basal) & & - \\
\hline Ornithischia indet. & - & \\
\hline \multicolumn{3}{|l|}{ Saurischia } \\
\hline \multicolumn{3}{|l|}{ Maniraptora } \\
\hline Dromaeosauridae indet. & & • \\
\hline Theropoda indet. & - & - \\
\hline \multicolumn{3}{|l|}{ Therapsida } \\
\hline $\begin{array}{l}\text { cf. Cynodontia indet. } \\
\text { morphotype } 1\end{array}$ & & - \\
\hline $\begin{array}{l}\text { cf. Cynodontia indet. } \\
\text { morphotype } 2\end{array}$ & & • \\
\hline \multicolumn{3}{|l|}{ Mammalia } \\
\hline \multicolumn{3}{|l|}{ Eutriconodonta } \\
\hline Dyskritodon amazighi & & $\bullet$ \\
\hline Gobiconodon palaios & & - \\
\hline Kryptotherium polysphenos & & - \\
\hline $\begin{array}{l}\text { Ichthyoconodon } \\
\text { jaworowskorum }\end{array}$ & & - \\
\hline Eutriconodonta indet. & & - \\
\hline
\end{tabular}

Table 4. (Continued)

\begin{tabular}{|c|c|c|}
\hline & $\begin{array}{c}\text { Guelb el Ahmar } \\
\text { (Anoual Formation) }\end{array}$ & $\begin{array}{l}\text { Ksar Metlili (Ksar } \\
\text { Metlili Formation) }\end{array}$ \\
\hline \multicolumn{3}{|l|}{ Haramiyida } \\
\hline Hahnodon taqueti & & • \\
\hline Denisodon moroccensis & & - \\
\hline \multicolumn{3}{|l|}{$\begin{array}{l}\text { 'Symmetrodonta' } \\
\text { (Trechnotheria) }\end{array}$} \\
\hline Atlasodon monbaroni & & $\cdot$ \\
\hline Microderson laaroussii & & - \\
\hline Thereuodon dahmanii & & - \\
\hline Minimus richardfoxi & & • \\
\hline Afriquiamus nessovi & & - \\
\hline Symmetrodonta indet. & & - \\
\hline \multicolumn{3}{|l|}{ Dryolestoidea } \\
\hline Donodon perscriptoris & & - \\
\hline Dryolestidae indet. & $\cdot$ & $\cdot$ \\
\hline \multicolumn{3}{|l|}{ Zatheria } \\
\hline Peramus sp. & & - \\
\hline Zatheria indet. & & $\cdot$ \\
\hline Amphitheriidae indet. & - & \\
\hline \multicolumn{3}{|l|}{ Cladotheria indet. } \\
\hline \multicolumn{3}{|l|}{ Stem Boreosphenida } \\
\hline Hypomylos phelizoni & & $\cdot$ \\
\hline Hypomylos micros & & - \\
\hline Tribotherium africanum & & $\cdot$ \\
\hline Vertebrata incertae sedis & $\bullet^{\star}$ & - \\
\hline
\end{tabular}

*referred to as 'Lissamphibia incertae sedis' in Haddoumi et al. (2016). The taxa in grey are shared by the GEA and KM faunas.

\section{6.c. New data on the dating of the Ksar Metlili site}

The 2010 expedition also resulted in the discovery of the new microvertebrate fossil locality of Guelb el Ahmar (GEA) in the Anoual Formation, which is stratigraphically right below the Ksar Metlili Formation, and where about 1.8 tons of sediments were sampled (Haddoumi et al. 2016). The GEA fossil locality is Bathonian (Middle Jurassic) in age, and it is one of the richest continental vertebrate assemblages from the Middle Jurassic of Gondwana (Haddoumi et al. 2016). The GEA and KM fossil localities from the Anoual Syncline are reference faunas documenting the evolution of vertebrates at or close to the Jurassic-Cretaceous transition, which remains noticeably poorly known in Africa and Gondwana.

The GEA fossil locality is less than $5 \mathrm{~km}$ northeast of the KM site, and it essentially consists of lacustrine deposits. The brachiopod fauna (Burmirhynchia gr. termeriae-aethiensis and Kallirhynchia oranensis) and, to a lesser extent, the ostracods and charophytes found in the marine upper member of the Anoual Formation strictly constrain the minimum age of the GEA fossil locality as early Bathonian (Haddoumi et al. 1998, 2016). The GEA faunal assemblage is taxonomically close to that of the KM 
fauna, except for some taxa that are missing in the GEA fauna (Table 4). This can be explained in different ways, but an important point is the difference in faunal richness between these two sites, KM being far richer than GEA despite a similar volume of sampled sediments (1.5 and 1.8 tons, respectively). Terrestrial vertebrates from the GEA fauna are less diversified and less abundant than aquatic ones, which is consistent with the lacustrine sedimentary facies of the GEA fossiliferous levels (Haddoumi et al. 2008). Moreover, the low-energy depositional (lacustrine) environment of the GEA locality did not concentrate fossil remains as much as in the KM locality, which explains the lower abundance (per square metre) and diversity of fossils in the GEA assemblage.

By contrast, some taxa are present in the GEA fauna but not in the KM fauna, for example the ionoscopiforms, metriorhynchids and stegosaurs (Table 4). Ionoscopiforms and metriorhynchids, two strictly aquatic taxa (Bardet, 1995; Brandalise de Andrade et al. 2010; Xu et al. 2014), confirm that the environment at the GEA site was more aquatic than at the KM site.

The KM and GEA faunas share numerous taxa (14 common taxa, Table 4), despite their noticeably distinct ages following current stratigraphic data and interpretation. The strong resemblance of these faunas seems to stand against the existence of a supposed major stratigraphic gap ( 23 Ma) between the Bathonian Anoual Formation and the Ksar Metlili Formation, thus questioning the inferred Berriasian age of the KM site (Sigogneau-Russell et al. 1990, 1998; Duffin \& Sigogneau-Russell, 1993; Haddoumi et al. 2008, 2016; Mojon et al. 2009). However, we cannot definitely exclude an Early Cretaceous age for the KM fauna for several reasons. The first and the most important one is that the recognized similarities between the KM fauna and the studied Jurassic faunas (GEA and Guimarota) are at higher systematic levels, owing to the numerous uncertainties in the determinations as a consequence of the poor state of preservation of the fossil material, which results in low taxonomic resolution. Another explanation is that some of the shared taxa with the GEA fauna could be long-lived taxa spanning the Middle Jurassic and Early Cretaceous periods, or that the African KM localities could be a refugium for vertebrates with Jurassic affinities, as are sites in Western Siberia (Ilek Formation) and Yakutia (Batylykh Formation) (Skutschas, 2016; Averianov et al. 2018; Skutschas et al. 2018). However, the close taxonomic resemblance of the GEA and KM faunas indicates that an age as old as Late Jurassic for the KM fauna cannot be excluded in the current state of understanding of their taxonomic composition.

The KM site is not the first vertebrate-yielding locality from the 'Continental Intercalaire' for which a Cretaceous or Jurassic age remains debated. In Morocco, the dating of the 'Red Beds' has always been debated because of the absence of reliable chronostratigraphic markers (see Section 2 above and Charrière \& Haddoumi, 2016, 2017 for more details). The Tiouaren Formation in Niger was assumed to be Lower Cretaceous by many authors (Lapparent, 1960; Taquet, 1976; Moody \& Sutcliffe, 1991; Mateer et al. 1992; Sereno et al. 1994, 1999, 2004), but even if the stratigraphic relationships of the Tiouaren Formation with the over- and underlying formations have helped to constrain its minimum age as Aptian, they do not provide a maximum age for that formation (Rauhut \& López-Arbarello, 2009). Some dinosaur taxa from the Tiouaren Formation would not be inconsistent with a preKimmeridgian Jurassic age (Rauhut \& López-Arbarello, 2009). In fact, it is likely that the Tiouaren Formation and the Moroccan 'Red Beds', both spanning a large time interval, contain faunas of different ages and thus the ages inferred from stratigraphic and faunal data cannot be attributed to the entire formation.

A better characterization of the age of the KM fauna requires some large-scale comparisons with subcontemporaneous faunas, such as those from the Bathonian of Kirtlington, Britain, the Upper Jurassic Morrison Formation, North America, or the Lower Cretaceous Purbeck Limestone Group of Britain. Such comparisons have never been done and are currently still in progress, but we provide here a preliminary comparison with the Guimarota site (Portugal) that has been dated as Kimmeridgian (Upper Jurassic) on the basis of the ostracod fauna (Schudack, 2000). This site has yielded a rich and diversified microvertebrate fauna (Zinke, 1998; Martin \& Krebs, 2000; Martin, 2001). The faunal assemblage from Guimarota shows affinity with that of the KM fauna at higher taxonomic levels. The two faunas share hybodont selachians (Kriwet, 2000, 2004), pycnodontiform actinopterygians (Kriwet, 2000, 2002), albanerpetontids (Wiechmann, 2000; Gardner et al. 2003), atoposaurids (Schwarz \& Salisbury, 2005), teleosaurids (Schwarz, 2002), ornithischian dinosaurs (Zinke, 1998; Rauhut, 2000, 2001), dromaeosaurid theropods (Zinke, 1998; Rauhut, 2000) and dryolestid and zatherian mammals (Martin, 1999, 2000, 2001, 2002). Considering all these taxa together, this faunal association is consistent with a possible Late Jurassic age for the KM fauna, although the high taxonomic-rank affinity with Guimarota does not permit a definitive conclusion.

The faunal assemblage from the Langenberg Quarry, in the upper Oxfordian to upper Kimmeridgian (Fischer, 1991) of northern Germany, also shows numerous affinities with the KM fauna. Hybodont selachians (Thies, 1995; A. Mudroch, unpub. Ph.D. thesis, Univ. Hannover, 2001), ginglymode, pycnodontiform and ionoscopiform actinopterygians (A. Mudroch, unpub. Ph.D. thesis, Univ. Hannover, 2001), paramacellodid lizards (Wings, 2015; Richter et al. 2013; Schwarz et al. 2017), teleosaurid and atoposaurid crocodylomorphs (Karl et al. 2006; Wings \& Sander, 2012; Wings, 2015; Schwarz et al. 2017), dromaeosaurid theropods (Lubbe et al. 2009) and dryolestid mammals (Wings, 2015) are shared between the two faunas. Like the previous comparison with the Guimarota mine, this comparison with the Langenberg Quarry fauna is a new consistent element to propose a possible Late Jurassic age for the KM fauna even if, again, these higher taxonomic-level affinities do not permit a definitive conclusion.

There seems to be some similarity in faunal composition between the KM site and the Lower-Middle Jurassic Kota Formation of India: teeth similar to those referred to the Atoposauridae and Dromaeosauridae are also known from the Kota Formation (G. V. R. Prasad, work in progress). The Kota Formation also shares the triconodont mammal Dyskritodon (D. indicus) with the KM site, and further haramiyid teeth have been recovered from this formation (G. V. R. Prasad, work in progress). Thus, the Kota Formation vertebrates may represent some of the few Gondwanan affinities of the KM fauna (see Section 6.d.1 below) and, because of its Lower-Middle Jurassic age (Prasad \& Manhas, 2002), it could be another argument to propose a possible Late Jurassic age for the KM fauna.

Besides faunal comparisons with the GEA and Guimarota faunas, other elements of discussion may argue for a Late Jurassic age for the KM fauna instead of Early Cretaceous. The ornithischian tooth described here (see Section 4.b.10.a above) has quite a simple morphology, compared to other Jurassic and Cretaceous ornithischians, such as Lycorhinus, Abrictosaurus, Heterodontosaurus, Nanosaurus or Hypsilophodon (Norman et al. 2004; Carpenter \& Galton, 2018). Because of its plesiomorphic morphology, it seems 
closely related to the early representatives of the group or could be a survivor of an ancient, basal lineage. Thus, this ornithischian tooth could argue in favour of a Jurassic age for the KM fauna. Another argument is the possible presence in the KM fauna of several relict lineages. This includes first the youngest known putative non-mammaliaform cynodonts outside Asia, with teeth that are morphologically close to those of Late Permian - Early Triassic species (see Section 4.b.11 above and references therein). It is more reasonable to hypothesize the survival of such an African relict lineage until the Late Jurassic rather than the Early Cretaceous. The same can be said about the presence of ?Gnathosaurinae pterosaurs, of which the KM species are among the latest representatives (see Section 4.b.9 above and references therein), and of haramiyidan mammaliaforms (see Section 4.b.12 above), which are scarce outside Eurasia (Huttenlocker et al. 2018).

The palaeobiogeography also gives clues concerning a possible reassessment of the age of the KM fauna to the Jurassic. There are many taxa with Pangaean affinities and only a few with Gondwanan affinities in the KM fauna, despite its location in Gondwana (see Section 6.d below). The most parsimonious explanation of such a strong Pangaean affinity of the fauna is that it remained close in time to the vicariant event resulting from the Jurassic Pangaean fragmentation. If so, then the KM fauna could be older than previously thought, i.e. of Jurassic age, even if we still cannot exclude the Cretaceous hypothesis.

\section{6.d. Palaeobiogeographical implications}

\section{6.d.1. Taxa with Gondwanan affinities}

During the Jurassic-Cretaceous transition, Africa was still sutured with South America in the West Gondwanan block, but the incipient opening of the Western Tethys and Central Atlantic Ocean drifted it away from Laurasia (Cecca et al. 1993; Gheerbrant \& Rage, 2006). Terrestrial faunal relationships between South America and Africa were possible until Aptian/Albian time. However, and unexpectedly, few taxa of Gondwanan affinities are currently identified in the KM fauna. They are only represented by osteoglossiform actinopterygians, cf. ptychoceratodontid lungfishes and ctenochasmatid pterosaurs. Other taxa, such as atoposaurids, dromaeosaurids and the mammal genus Dyskritodon (G. V. R. Prasad, work in progress), may represent Gondwanan affinities of the KM fauna, but we cannot exclude a transTethyan dispersal from a Laurasian origin or an old Pangaean distribution for those taxa (see Sections 6.d.2 and 6.d.3 below). More generally, the known faunal relationships and dispersals between Africa and other Gondwanan continents are paradoxically scarce during the entire Cretaceous period (Gheerbrant \& Rage, 2006). There is no taxon of Gondwanan affinity in the GEA fauna, with the possible exception of the dipnoan Arganodus, which seems to be present in Gondwana between the Triassic and Cretaceous periods (Soto \& Perea, 2010; Haddoumi et al. 2016).

\section{6.d.2. Taxa with Laurasian affinities: evidence for trans-Tethyan dispersals}

In contrast to the occurrence of few Gondwanan taxa, the KM fauna includes numerous vertebrate taxa with Laurasian affinities that suggests either vicariance or dispersal events between Laurasia and Africa during Late Jurassic or Early Cretaceous times. An old Pangaean distribution cannot be excluded for some of these taxa based on the current state of the data presented here, but some other taxa clearly favour dispersal events.
The albanerpetontid and alytid anurans, previously unknown in Gondwana during Jurassic and Early Cretaceous times, are thought to be of Laurasian origin (Gheerbrant \& Rage, 2006). Their presence in the KM fauna, at the time of Pangaean fragmentation, results either from a vicariance event or more likely from a N-S trans-Tethyan dispersal event (Gheerbrant \& Rage, 2006). The hypothesis of a trans-Tethyan dispersal of the albanerpetontid and alytid anurans requires the existence of a terrestrial route across the Tethys, because the sea is an effective barrier for the dispersal of amphibians. It could have been provided by the Mediterranean Tethyan Sill during low eustatic levels (Vrielynck et al. 1995; Dercourt et al. 2000). Paramacellodid squamates, such as Paramacellodus marocensis from the KM fauna, are well known in Laurasia but have only two occurrences in Gondwana (Tendaguru, in the Upper Jurassic of Tanzania, and KM; Broschinski \& Sigogneau-Russell, 1996; Broschinski, 1999); so, the hypothesis of a trans-Tethyan dispersal from Laurasia towards Africa is plausible, although we cannot exclude a possible old Pangaean distribution. Choristoderan reptiles and atoposaurid crocodylomorphs are exclusively known in Laurasia during this period (Matsumoto et al. 2013; Tennant \& Mannion, 2014; Tennant et al. 2016), but have Gondwanan occurrences as early as Bathonian time (from Morocco and Madagascar; Flynn et al. 2006; Haddoumi et al. 2016); thus, a trans-Tethyan dispersal of these two groups is possible, although, and again, we cannot definitely exclude the Pangaean vicariance hypothesis.

Several mammals found in the KM fauna are also most likely of Laurasian origin. For example, the triconodont Gobiconodon and the 'symmetrodont' Thereuodon are known from the Jurassic and the Lower Cretaceous of Laurasia (Sigogneau-Russell \& Ensom, 1998; Sigogneau-Russell, 2003; Kielan-Jaworowska et al. 2004; Gheerbrant \& Rage, 2006; J. Pouech, unpub. Ph.D. thesis, Claude Bernard - Lyon 1 University, 2008; Butler \& SigogneauRussell, 2016). The gobiconodontid (eutriconodont) Gobiconodon palaios from the KM fauna seems to be close to G. bathoniensis from the Middle Jurassic of Great Britain (Butler \& SigogneauRussell, 2016), and Thereuodon dahmani from the KM fauna is close to T. taraktes from the Lower Cretaceous of Britain (Sigogneau-Russell \& Ensom, 1998), which stands in favour of a trans-Tethyan dispersal of these genera. Likewise, dryolestoids are known only in Laurasia before the Late Cretaceous period, which indicates a Laurasian origin for the group (KielanJaworowska et al. 2004). Their presence in the KM fauna can be indeed explained by a trans-Tethyan dispersal event (but see Section 6.d.3 below). The KM fauna also includes the stem boreosphenidans Hypomylos and Tribotherium, which are the oldest known tribosphenidans (= Boreosphenida; Luo et al. 2001) in Africa. On a global scale, they are even among the first representatives of the tribosphenidans (Sigogneau-Russell, 1991c; KielanJaworowska et al. 2004). The Laurasian diversity and the phylogenetic relationships of the Tribosphenida suggest a Laurasian origin for this group (Luo et al. 2001, 2002, 2003). The two stem boreosphenidan species from the KM site further support the hypothesis of one or more dispersal events between Laurasia and Africa by the beginning of the Cretaceous period and possibly well back into Late Jurassic time. The KM fauna provides additional data showing that trans-Tethyan biotic interchanges between Laurasia and Africa were not minor and accidental events (Gheerbrant \& Rage, 2006) and may have occurred as early as the Jurassic period.

As for the KM fauna, previous studies (Haddoumi et al. 2016) have shown that the GEA fauna displays noticeable affinities with Laurasian faunas, with the presence of albanerpetontids, caudatan 
amphibians, anguimorph squamates, choristoderes, amphitheriids, dryolestoids and stem boreosphenidans (Table 4; Haddoumi et al. 2016). Moreover, the atoposaurid teeth from the GEA and $\mathrm{KM}$ faunas represent some of the scarce occurrences of this group in Gondwana (Haddoumi et al. 2016); atoposaurids are instead well known in Laurasia. However, because of their presence in both the KM and GEA faunas, we cannot exclude an old cosmopolitan distribution for all or part of these taxa, which thus could be vicariant Pangaean taxa.

\section{6.d.3. Pangaean vicariant taxa}

Several taxa from the KM fauna, including mammals, suggest a likely old inherited Pangaean distribution. This includes the hahnodontids that were initially described as belonging to an endemic African multituberculate family during Early Cretaceous time (Sigogneau-Russell, 1991b; Hahn \& Hahn, 2003). Their recent discovery in the Lower Cretaceous of North America led Huttenlocker et al. (2018) to the inclusion of the family in the Haramiyida, and to explaining their presence in both North America and Africa by the existence of Pangaea-wide dispersal corridors, accessible to relictual clades of vertebrates such as haramiyidans. However, an old Pangaean distribution seems more likely because of the already reported presence of haramiyidans in the African Jurassic (Tanzania; Heinrich, 1999, 2001, 2004) and the Indian Jurassic and Cretaceous (Anantharam et al. 2006; G. V. R. Prasad, work in progress). The dryolestoids are known to occur in the Upper Jurassic and Lower Cretaceous of both Europe and North America and in the Upper Cretaceous of South America (Kielan-Jaworowska et al. 2004; Cifelli et al. 2014), which cannot exclude their wider early distribution in both Gondwana and Laurasia. Triconodontids are known from as early as the Jurassic of South America, with Argentoconodon fariasorum (Gaetano \& Rougier, 2010, 2011); this species shares four unambiguous synapomorphies with Ichthyoconodon jaworowskorum from the KM fauna and with Volaticotherium antiquus from the Middle Jurassic of China (see Gaetano \& Rougier, 2007, 2010, 2011). These three species thus represent a monophyletic group of triconodontids, the tribe Volaticotherini, nested within the Alticonodontinae (Gaetano \& Rougier, 2011). Considering the Early Jurassic age of A. fariasorum, ghost lineages for Ichthyoconodon and Volaticotherium must extend back at least to Early Jurassic time. Ichthyoconodon might have arisen from vicariant evolution in Africa following Pangaean fragmentation (Gheerbrant \& Rage, 2006). The genus Dyskritodon might also have had an old Pangaean distribution, because of the presence of the species D. indicus in the Lower or Middle Jurassic of India (Prasad \& Manhas, 2002). The following other non-mammalian taxa from the KM fauna also have Pangaean affinities: the ginglymodians of cosmopolitan distribution; the ionoscopiform actinopterygians, widely distributed in Europe, Africa and the Americas from the Middle Triassic to the end of the Cretaceous period (Vullo \& Courville, 2014); the mawsoniid actinistians of Pangaean Triassic distribution (Miguel et al. 2014); the rhynchocephalians, known from the Triassic in Europe, Madagascar and the Americas, and from the Lower Jurassic in Asia, Africa and India (Evans et al. 2001; Martínez et al. 2013); the scincomorphans, present in North America, Europe and Africa since Late Jurassic time (Evans, 2003) and in Asia since Middle Jurassic time (Averianov et al. 2016); and the teleosaurid crocodylomorphs that have a cosmopolitan distribution in Middle Jurassic time (Haddoumi et al. 2016). Apart from triconodontid mammals, all these taxa are also present in the GEA fauna (Table 4; Haddoumi et al. 2016), which is significant.

\section{6.d.4. African endemism}

Some of the KM taxa seems to be endemic to Africa or even to North Africa, despite its connection with South America and thus with other Gondwanan landmasses. Some taxa, such as stem zatherian and boreosphenids, are present in the KM fauna but unknown in South America (Kielan-Jaworowska et al. 2004). Australosphenids are known in the whole of Gondwana during that time, except in Africa (Kielan-Jaworowska et al. 2004). The hypothesis of a North African provincialism, with a geographic and/or biological isolation of North Africa within Africa and Gondwana before the separation of Africa and South America, has been suggested in previous studies (Gheerbrant \& Rage, 2006; Haddoumi et al. 2016): it could explain the presence of some taxa in North Africa but not in South America, and the absence of others from North Africa despite their presence in South America. No significant endemism has been detected in the GEA vertebrate fauna, but this fauna is still poorly documented, so this is not a definitive statement (Haddoumi et al. 2016).

\section{6.d.5. Summary of the palaeobiogeographical significance of} the KM fauna

The current study of the KM fauna shows that it has, as a whole, a complex palaeobiogeographical composition. This North African fauna includes a predominant number of vicariant Pangaean taxa. It also includes several Laurasian immigrants implying transTethyan dispersals. The involved dispersal events might be as early as Middle Jurassic for the taxa that were already present in the GEA fauna (albanerpetontids, choristoderes, atoposaurids and dryolestoids mammals), although we cannot exclude that the Jurassic taxa known in the GEA fauna could alternatively have an old Pangaean distribution. The Gondwanan taxa are by contrast few in the KM fauna, as was already noted in the GEA fauna (Haddoumi et al. 2016). Some endemic taxa also suggest evolution in the context of a ?Jurassic North African provincialism.

\section{Conclusions}

The KM and GEA fossil localities from the Anoual Syncline provide critical fossil data on the palaeobiodiversity and evolution of vertebrate faunas from the Middle-Upper Jurassic/Lower Cretaceous of Africa and Gondwana, which remain poorly known. Their unrivalled richness and diversity open an exceptional window on the Mesozoic palaeoecosystems of Africa. Considering both the old and new collections from the KM locality, at least 47 distinct species are identified. Some of them, such as mammals, are highly diversified in the KM fauna. The Crocodylomorpha is the dominant taxon, which indicates a more terrestrial environment at the KM than at the GEA site. A predominating four-taxa association is identified: actinopterygians, crocodylomorphs, pterosaurs and turtles, representing more than $95 \%$ in relative abundance of the recovered fossil material. The KM fossil locality has produced some remarkable taxa including the oldest possible? Siluriformes or ?Polypteriformes, the earliest Gondwanan record of caecilians and alytids, and one of the scarce Gondwanan records of albanerpetontids (with the albanerpetontid genus Anoualerpeton also recorded from the Middle Jurassic of England) and of choristoderes. Ksar Metlili also yielded one of the first occurrences of freshwater teleosaurids and an ornithischian with surprisingly primitive dental features relative to other 
contemporaneous ornithischians. Finally, the KM locality preserves some of the last-known non-mammalian cynodonts outside Asia and some of the first-known stem boreosphenidan mammals, which are also the earliest known from Africa. Moreover, the KM fauna has a complex composite palaeobiogeographic history: it is mainly composed of taxa with Pangaean and Laurasian affinities, whereas only a few Gondwanan taxa have been found. This assemblage seems to be the result of Pangaean fragmentation and vicariance and of several trans-Tethyan dispersal events in Africa. The taxonomic comparisons between the GEA, Guimarota and KM faunas provide new data questioning the previously proposed earliest Cretaceous age for the KM fauna. The taxonomic similarities between these three key faunas seem to stand against the existence of an important time gap between the microvertebrate sites from the Anoual and Ksar Metlili formations. This leads us to conclude that a Late Jurassic age for the KM fauna, instead of Early Cretaceous, still cannot be rejected.

The study of the KM fauna is still in progress. Turtles, crocodiles, non-mammalian cynodonts and several mammal taxa have to be further studied, and the taxonomy of lissamphibians and theropods must be revised. More fossil remains from the KM locality, currently in preparation, might provide important data on the palaeobiodiversity, evolutionary and palaeobiogeographical history of African and Gondwanan vertebrates during the Jurassic period.

Acknowledgements. This paper is dedicated to the memory of our friend and co-author Jean-Claude Rage, who suddenly passed away on March 30, 2018. We thank S. Jouve (Sorbonne Université) and J. P. Tennant (Imperial College London) for discussions on crocodylomorphs and especially on the teleosaurids and atoposaurids. We thank G. Clément for his help with the identification of the coelacanth. Thanks also to J. E. Martin for discussions on the ornithischian tooth. We thank M. Debuysschere (CR2P, MNHN), F. Abdala (University of the Witwatersrand) and S. C. Sweetman (University of Portsmouth) for their help and discussions on non-mammaliaform cynodonts. We thank L. Cazes and P. Loubry (CR2P, MNHN) for the photographs. We are grateful to A. Gailliègue (ISCD, Sorbonne Université) for the script 'Count Image Elements' that she specially developed for this study and which has been very helpful for the counting of the numerous specimens. We also want to thank M. Forissier, J. Marchand and V. Prugneaux (SAGA) for their assistance in the long and difficult sorting of the clastic samples. We are grateful to A. Benlakhdim (Ministry of Energy, Mines and Sustainable Development, Morocco) for the field work authorization. We thank P. Skutschas, three anonymous reviewers and the editor, for their corrections and useful comments which helped to improve the manuscript. The 2010 field work in Anoual area (Morocco) that allowed the recovery of the KM and GEA material was supported by the National Geographic Society (CRE GRANT \#8706-09; PI: E. Gheerbrant).

Supplementary Material. To view supplementary material for this article, please visit https://doi.org/10.1017/S0016756819000761.

\section{References}

Allain R and Aquesbi N (2008) Anatomy and phylogenetic relationships of Tazoudasaurus naimi (Dinosauria, Sauropoda) from the late Early Cretaceous of Morocco. Geodiversitas 30, 345-424.

Allain R and Läng E (2009) Origine et evolution des Saurischiens. Comptes Rendus Palevol 8, 243-56. doi: 10.1016/j.crpv.2008.09.013

Anantharam S, Wilson GP, Das Sarma DC and Clemens WA (2006) A possible Late Cretaceous "Haramiyidan" from India. Journal of Vertebrate Paleontology 26, 488-90.

Argyriou T, Cook TD, Muftah AM, Pavlakis P, Boaz NT and Murray AM (2015) A fish assemblage from an Early Miocene horizon from Jabal Zaltan, Lybia. Journal of African Earth Sciences 102, 86-101. doi: 10.1016/ j.jafrearsci.2014.11.008
Averianov AO, Martin T and Bakirov AA (2005) Pterosaur and dinosaur remains from the Middle Jurassic Balabansai Svita in the Northern Fergana Depression, Kyrgyzstan (Central Asia). Palaeontology 48, 135-55. doi: 10.1111/j.1475-4983.2004.00437.x

Averianov AO, Martin T, Evans SE and Bakirov AA (2006) First Jurassic Choristodera from Asia. Naturwissenschaften 93, 46-50. doi: 10.1007/ s00114-005-0061-2

Averianov AO, Martin T, Lopatin AV, Schultz JA, Skutschas PP, Rico S and Krasnolutskii SA (2017) A tritylodontid synapsid from the Middle Jurassic of Siberia and the taxonomy of derived tritylodontids. Journal of Vertebrate Paleontology 37 e1363767, 11 pp. doi: 10.1080/02724634.2017.1363767

Averianov AO, Martin T, Lopatin AV, Skutschas PP, Schellhorn R, Kolosov P and Vitenko D (2018) A high-latitude fauna of mid-Mesozoic mammals from Yakutia, Russia. PLoS ONE 13 e0199983, 17 pp. doi: 10.1371/journal. pone.0199983

Averianov AO, Martin T, Skutschas PP, Danilov I, Schultz JA, Schellhorn R, Obraztsova E, Lopatin AV, Sytchevskaya E, Kuzmin I, Krasnolutskii SA and Ivantsov SV (2016) Middle Jurassic assemblage of Berezovsk coal mine in Western Siberia. Global Geology 19, 187-204. doi: 10.3969/j.issn.16739736.2016.04.01

Avrahami HM, Gates TA, Heckert AB, Makovicky PJ and Zanno LE (2018) A new microvertebrate assemblage from the Mussentuchit Member, Cedar Mountain Formation: insights into the paleobiodiversity and paleobiogeography of early Late Cretaceous ecosystems in western North America. PeerJ 6, e5883, 52 pp. doi: 10.7717/peer. 5883

Bardet N (1995) Évolution et extinction des reptiles marins au cours du Mésozoïque. Palaeovertebrata 24, 177-283.

Berendse F and Scheffer M (2009) The angiosperm radiation revisited, an ecological explanation for Darwin's 'abominable mystery'. Ecology Letters 12, 865-72. doi: 10.1111/j.1461-0248.2009.01342.x

Biddle JP and Landemaine O (1988) Contribution à l'étude des Sélaciens du bassin de Paris : découverte de quelques nouvelles espèces associées à une faune de type wealdien dans le Barrémien supérieur, Crétacé inférieur, des environs de Troyes (Aube). Musée de Saint-Dizier, Cahier 2, 1-22.

Blakey RC (2008) Gondwana paleogeography from assembly to breakup-A 500 m.y. odyssey. In Resolving the Late Paleozoic Ice Age in Time and Space (eds CR Fielding, TD Frank and JL Isbell), pp. 1-28. Geological Society of America, Special Paper no. 441.

Blob RW and Fiorillo AR (1996) The significance of vertebrate microfossil size and shape distributions for faunal abundance reconstructions: a Late Cretaceous example. Paleobiology 22, 422-35. doi: 10.1017/S0094837300016377

Brandalise de Andrade M, Young MT, Desojo JB and Brusatte SL (2010) The evolution of extreme hypercarnivory in Metriorhynchidae (Mesoeucrocodylia: Thalattosuchia) based on evidence from microscopic denticle morphology. Journal of Vertebrate Paleontology 30, 1451-65. doi: 10.1080/02724634.2010.501442

Brinkman DB (1990) Paleoecology of the Judith River Formation (Campanian) Of Dinosaur Provincial Park, Alberta, Canada: evidence from vertebrate microfossil localities. Palaeogeography, Palaeoclimatology, Palaeoecology 78, 37-54. doi: 10.1016/0031-0182(90)90203-J

Brinkman DB, Russell AP, Eberth DA and Peng J (2004) Vertebrate paleocommunities of the lower Judith River Group of southeastern Alberta, Canada, as interpreted from vertebrate microfossil assemblages. Palaeogeography, Palaeoclimatology, Palaeoecology 213, 295-313. doi: 10. 1016/j.palaeo.2004.07.016

Broschinski A (1999) Ein Lacertilier (Scincomorpha, Paramacellodidae) aus dem Oberen Jura von Tendaguru (Tansania). Mitteilungen aus dem Museum für Naturkunde zu Berlin, Geowissenschaftliche Reihe 2, 155-58. doi: 10.1002/mmng.1999.4860020111

Broschinski A and Sigogneau-Russell D (1996) Remarkable lizard remains from the Lower Cretaceous of Anoual (Morocco). Annales de Paléontologie (Vertébrés-Invertébrés) 82, 174-5.

Buffetaut E and Jeffery P (2012) A ctenochasmatid pterosaur from the Stonesfield Slate (Bathonian, Middle Jurassic) of Oxfordshire, England. Geological Magazine 149, 552-6. doi: 10.1017/S0016756811001154

Butler PM and Sigogneau-Russell D (2016) Diversity of triconodonts in the Middle Jurassic of Great Britain. Palaeontologia Polonica 67, 35-65. doi: 10.4202/pp.2016.67_035 
Caldwell MW, Nydam RL, Palci A and Apesteguía S (2015) The oldest known snakes from the Middle Jurassic-Lower Cretaceous provide insights on snake evolution. Nature Communications 6, 1-11. doi: 10.1038/ncomms6996

Carpenter K and Galton PM (2018) A photo documentation of bipedal ornithischians dinosaurs from the Upper Jurassic Morrison Formation, USA. Geology of the Intermountain West 5, 167-207.

Cecca F, Azema J, Fourcade E, Baudin F, Guiraud R and Dever P (1993) Early Kimmeridgian Palaeoenvironments (146-144 Ma) Map 1:20,000,000. In Atlas Tethys Palaeoenvironmental Maps (eds J Dercourt, LE Ricou and B Vrielynck). Paris:CCGM.

Charrière A and Haddoumi H (2016) Les 'Couches rouges' continentales jurassico-crétacées des Atlas marocains (Moyen Atlas, Haut Atlas central et oriental): bilan stratigraphique, paléogéographies successives et cadre géodynamique. Boletín Geológico y Minero 127, 407-30.

Charrière A and Haddoumi H (2017) Dater les couches rouges continentales pour définir la géodynamique atlasique. Géologues 194, 29-32.

Cifelli RL, Davis BM and Sames B (2014) Earliest Cretaceous mammals from the western United States. Acta Palaeontologica Polonica 59, 31-52. doi: 10. 4202/app.2012.0089

Cifelli RL, Lipka TR, Schaff CR and Rowe TB (1999) First Early Cretaceous mammal from the eastern seaboard of the United States. Journal of Vertebrate Paleontology 19, 199-203. doi: 10.1080/02724634.1999.10011134

Clemens WA, Goodwin MB, Hutchinson JH, Schaff CR, Wood CB and Colbert MW (2007) First record of a Jurassic mammal (?"Peramura") from Ethiopia. Acta Palaeontologica Polonica 52, 433-9.

Cullen TM, Fanti F, Capobianco C, Ryan MJ and Evans DC (2016) A vertebrate microsite from a marine-terrestrial transition in the Foremost Formation (Campanian) of Alberta, Canada, and the use of faunal assemblage data as palaeoenvironmental indicator. Palaeogeography, Palaeoclimatology, Palaeoecology 444, 101-14. doi: 10.1016/j.palaeo.2015. 12.015

Daget J, Gayet M, Meunier FJ and Sire J-Y (2001) Major discoveries on the dermal skeleton of fossil and Recent polypteriforms: a review. Fish and Fisheries 2, 113-24.

Datta PM, Das DP, Luo ZX (2004) A Late Triassic dromatheriid (Synapsida: Cynodontia) from India. Annals of Carnegie Museum 73, 72-84.

Dercourt J, Gaetani M, Vrielynck B, Barrier E, Biju-Duval B, Brunet MF, Cadet JP, Crasquin S and Sandulescu M (eds) (2000) Atlas Peri-Tethys Palaeogeographical Maps. Paris: Commission de la carte géologique du monde, 24 pp.

Duffin CJ and Sigogneau-Russell D (1993) Fossil shark teeth from the Early Cretaceous of Anoual, Morocco. Belgian Geological Survey Professional Paper 264, 175-90.

Estes R and Berberian P (1970) Paleoecology of a Late Cretaceous vertebrate community of from Montana. Breviora 343, 1-35.

Evans SE (1991) The postcranial skeleton of the choristodere Cteniogenys (Reptilia: Diapsida) from the Middle Jurassic of England. Geobios 24, 187-99. doi: 10.1016/S0016-6995(91)80006-L

Evans SE (2003) At the feet of the dinosaurs: the early history and radiation of lizards. Biological Review 78, 513-51. doi: 10.1017/S1464793103006134

Evans SE and Jones MEH (2010) The origin, early history and diversification of lepidosauromorph reptiles. In New Aspects of Mesozoic Biodiversity (ed. S Bandyopadhyay), pp. 27-44. Lecture Notes in Earth Sciences no. 132. Berlin: Springer-Verlag.

Evans SE, Prasad GVR and Manhas BK (2001) Rhynchocephalians (Diapsida: Lepidosauria) from the Jurassic Kota Formation of India. Zoological Journal of the Linnean Society 133, 309-34. doi: 10.1006/zjls.2000.0266

Evans SE and Sigogneau-Russell D (1997) New sphenodontians (Diapsida: Lepidosauria: Rhynchocephalia) from the Early Cretaceous of North Africa. Journal of Vertebrate Paleontology 17, 45-51. doi: 10.1080/ 02724634.1997.10010952

Evans SE and Sigogneau-Russell D (2001) A stem-group caecilian (Lissamphibia: Gymnophiona) from the Lower Cretaceous of North Africa. Palaeontology 44, 259-73. doi: 10.1111/1475-4983.00179

Fischer R (1991) Die Oberjura-Schichtenfolge des Langenbergs bei Oker. Arbeitskreis Paläontologie Hannover 19, 21-36.

Flynn JJ, Fox SR, Parrish JM, Ranivoharimanana L and Wyss AR (2006) Assessing diversity and paleoecology of a Middle Jurassic microvertebrate assemblage from Madagascar. In The Triassic-Jurassic Terrestrial Transition (eds JD Harris, SG Lucas, JA Spielmann, MG Lockley, ARC Milner \& JI Kirkland), pp. 476-89. New Mexico Museum of Natural History and Science Bulletin no. 37.

Frederickson JA, Lipka TR and Cifelli RL (2018) Faunal composition and paleoenvironment of the Arundel Clay (Potomac Formation; Early Cretaceous), Maryland, USA. Palaeontologica Electronica 21.2.31A, 1-24. doi: $10.26879 / 847$

Gaetano LC and Rougier GW (2007) New triconodont specimens from the Middle Jurassic of Patagonia. Ameghiniana 44, 19R.

Gaetano LC and Rougier GW (2010) New specimens and phylogenetic relationships of the South American Jurassic triconodont Argentoconodon fariasorum. Journal of Vertebrate Paleontology 28, 93A. doi: 10.1080/02724634. 2011.589877

Gaetano LC and Rougier GW (2011) New materials of Argentoconodon fariasorum (Mammaliaformes, Triconodontidae) from the Jurassic of Argentina and its bearing on triconodont phylogeny. Journal of Vertebrate Paleontology 31, 829-43. doi: 10.1080/02724634.2011.589877

Gardner JD, Evans SE and Sigogneau-Russell D (2003) New albanerpetontid amphibians from the Early Cretaceous of Morocco and Middle Jurassic of England. Acta Palaeontologica Polonica 48, 301-19.

Gayet M and Meunier FJ (2003) Palaeontology and palaeobiogeography of catfishes. Catfishes 2, 491-522.

Gayet M, Meunier FJ and Werner C (2002) Diversification in Polypteriformes and special comparison with Lepisosteiformes. Palaeontology 45, 361-76. doi: $10.1111 / 1475-4983.00241$

Gayet M and Otero O (1999) Analyse de la paléodiversification des Siluriformes. Geobios 32, 235-46. doi: 10.1016/S0016-6995(99)80037-0

Gheerbrant E and Rage J-C (2006) Paleobiogeography of Africa: how distinct from Gondwana and Laurasia? Palaeogeography, Palaeoclimatology, Palaeoecology 241, 224-46. doi: 10.1016/j.palaeo.2006.03.016

Gmira S (1995) Étude des chéloniens fossiles du Maroc: anatomie, systématique, phylogénie. Cahiers de Paléontologie 25, 1-174.

Godefroit P and Battail B (1997) Late Triassic cynodonts from Saint-Nicolasde-Port (north-eastern France). Geodiversitas 19, 567-31.

Haddoumi H, Allain R, Meslouh S, Métais G, Monbaron M, Pons D, Rage J-C, Vullo R, Zouhri S and Gheerbrant E (2016) Guelb el Ahmar (Bathonian, Anoual Syncline, eastern Morocco): first continental flora and fauna including mammals from the Middle Jurassic of Africa. Gondwana Research 29, 290-319. doi: 10.1016/j.gr.2014.12.004

Haddoumi H, Alméras Y, Bodergat AM, Charrière A, Mangold C and Benshili K (1998) Âges et environnements des Couches rouges d'Anoual (Jurassique moyen et Crétacé inférieur, Haut-Atlas oriental, Maroc). Comptes Rendus de l'Académie des Sciences de Paris Série II 327, 127-33. doi: 10.1016/S1251-8050(98)80043-8

Haddoumi H, Charrière A, Andreu B and Mojon PO (2008) Les dépôts continentaux du Jurassique moyen au Crétacé inférieur dans le Haut-Atlas oriental (Maroc): paléoenvironnements successifs et signification paléogéographique. Carnets de Géologie, Brest, Mémoire 2008/06, 29 pp. doi: $10.4267 / 2042 / 18122$

Hahn G and Hahn R (2003) New multituberculate teeth from the Early Cretaceous of Morocco. Acta Palaeontologica Polonica 48, 349-56.

Heimhofer U, Hochuli PA, Burla S and Weissert H (2005) New records of Early Cretaceous angiosperm pollen from Portuguese coastal deposits: implications for the timing of the early angiosperm radiation. Review of Palaeobotany and Palynology 144, 39-76. doi: 10.1016/j. revpalbo.2005.09.006

Heinrich WD (1999) First haramiyid (Mammalia, Allotheria) from the Mesozoic of Gondwana. Fossil Record 2, 159-70. doi: 10.1002/mmng. 1999.4860020112

Heinrich WD (2001) New record of Staffia aenigmantica (Mammalia, Allotheria, Haramiyida) from the Upper Jurassic of Tendaguru in southeastern Tanzania, East Africa. Fossil Record 4, 239-55. doi: 10.1002/ mmng.20010040114

Heinrich WD (2004) Allostaffia, a new genus name for Staffia Heinrich, 1999 (Allotheria, Haramiyida) preoccupied by Staffia Schubert, 1911 (Protista, Foraminifera). Fossil Record 7, 153. doi: 10.1002/mmng.20040070108 
Hendrickx C, Mateus O and Araújo R (2015) The dentition of megalosaurid theropods. Acta Palaeontologica Polonica 60, 627-42. doi: 10.4202/app. 00056.2013

Hochuli PA, Heimhofer U and Weissert H (2006) Timing of early angiosperm radiation: recalibrating the classical succession. Journal of the Geological Society, London 163, 587-94. doi: 10.1144/0016-764905-135

Holman JA (2003) Fossil Frogs and Toads of North America. Bloomington: Indiana University Press, $264 \mathrm{pp}$.

Humphries S, Bonser RHC, Witton MP and Martill DM (2007) Did pterosaurs feed by skimming? Physical modelling and anatomical evaluation of an unusual feeding method. PLoS Biology 5 e204. doi: 10.1371/journal.pbio. 0050204

Huttenlocker AK, Grossnickle DM, Kirkland JI, Schultz JA and Luo Z-X (2018) Late-surviving stem mammal links the lowermost Cretaceous of North America and Gondwana. Nature 558, 108-12. doi: 10.1038/s41586018-0126-y

Jamniczky HA, Brinkman DB and Russell AP (2008) How much is enough? A repeatable, efficient, and controlled sampling protocol for assessing taxonomic diversity and abundance in vertebrate microfossil assemblages. In Vertebrate Microfossil Assemblages: Their Role in Paleoeocology and Paleobiogeography (eds JT Sankeyand S Baszio), pp. 9-16. Bloomington: Indiana University Press.

Ji Q, Luo Z-X, Yuan CX, Wible JR, Zhang JP and Georgi JA (2002) The earliest known eutherian mammal. Nature 416, 816-22. doi: 10.1038/416816a

Jones MEH, Evans SE and Sigogneau-Russell D (2003) Early Cretaceous frogs from Morocco. Annals of Carnegie Museum 72, 65-97.

Karl HV, Gröning E, Brauckmann C, Schwarz D and Knötschke N (2006) The Late Jurassic crocodiles of the Langenberg near Oker, Lower Saxony (Germany), and description of related materials (with remarks on the history of quarrying the "Langenberg Limestone" and "Obernkirchen Sandstone"). Clausthaler Geowissenschaften 5, 59-77.

Kielan-Jaworowska Z, Cifelli RL and Luo Z-X (2004) Mammals from the Age of Dinosaurs: Origins, Evolution and Structure. New York: Columbia University Press, 640 pp.

Kielan-Jaworowska Z and Dashzeveg D (1998) Early Cretaceous amphilestid ('triconodont') mammals from Mongolia. Acta Palaeontologica Polonica 43, $413-38$.

Kilian C (1931) Des principaux complexes continentaux du Sahara. Comptes Rendus de la Société géologique de France 9, 109-11.

Knoll F (2000) Pterosaurs from the Lower Cretaceous (?Berriasian) of Anoual, Morocco. Annales de Paléontologie 86, 157-64. doi: 10.1016/S0753-3969(00) 80006-3

Knoll F and Ruiz-Omeñaca JI (2009) Theropod teeth from the basalmost Cretaceous of Anoual (Morocco) and their palaeobiogeographical significance. Geological Magazine 146, 602-16. doi: 10.1017/S0016756809005950

Kovalchuk O and Ferraris CJ (2016) Late Cenozoic catfishes of southeastern Europe with inference to their taxonomy and palaeogeography. Palaeontologia Electronica 19.3.34A, 17 pp. doi: $10.26879 / 616$

Kriwet J (2000) The fish fauna from the Guimarota mine. In Guimarota: A Jurassic Ecosystem (eds T Martinand B Krebs), pp. 41-50. Munich: Verlag Dr. Friedrich Pfeil.

Kriwet J (2002) Pycnodont fish remains (Neopterygii: Pycnodontiformes) from the Kimmeridgian (Upper Jurassic) of the Lusitanian Basin (Central Portugal). Neues Jahrbuch für Geologie und Paläontologie Monatshefte 10, 577-87.

Kriwet J (2004) Late Jurassic selachians (Chondrichthyes: Hybodontiformes, Neoselachii) from Central Portugal. Neues Jahrbuch für Geologie und Paläontologie Monatshefte 4, 233-56.

Lapparent AF de (1960) Les Dinosauriens du "Continental Intercalaire" du Sahara central. Mémoires de la Société géologique de France (Nouvelle Série) 88A, 1-57.

Lasseron M (2019) Enigmatic teeth from the Jurassic-Cretaceous transition of Morocco: the latest known non-mammaliaform cynodonts (Synapsida, Cynodontia) from Africa? Comptes Rendus Palevol, published online 9 July 2019. doi: 10.1016/j.crpv.2019.05.002

Li ZX, Powell CMcA (2001) An outline of the palaeogeographic evolution of the Australasian region since the beginning of the Neoproterozoic. EarthScience Reviews 53, 237-77. doi: 10.1016/S0012-8252(00)00021-0
Lopatin AV and Agadjanian AK (2008) A tritylodont (Tritylodontidae, Synapsida) from the Mesozoic of Yakutia. Doklady Biological Sciences 419, 279-82. doi: 10.1134/S0012496608020117

Lubbe T van der, Richter U and Knötschke N (2009) Velociraptorine dromaeosaurid teeth from the Kimmeridgian (Late Jurassic) of Germany. Acta Palaeontologica Polonica 54, 401-8. doi: 10.4202/app.2008.0007

Lucas SG and Oakes W (1988) A Late Triassic cynodont from the American South-West. Palaeontology 31, 445-9.

Luo Z-X, Cifelli RL and Kielan-Jaworowska Z (2001) Dual origin of tribosphenic mammals. Nature 409, 53-7. doi: 10.1038/35051023

Luo Z-X, Ji K, Wible JR and Yuan CX (2003) An Early Cretaceous tribosphenic mammal and metatherian evolution. Science 302, 1934-40. doi: 10. 1126/science.1090718

Luo Z-X, Kielan-Jaworowska Z and Cifelli RL (2002) In quest for a phylogeny of Mesozoic mammals. Acta Palaeontologica Polonica 47, 1-78.

Luo Z-X, Yuan CX, Meng QJ and Ji Q (2011) A Jurassic eutherian mammal and divergence of marsupials and placentals. Nature 476, 442-5. doi: 10. 1038/nature10291

Marjanović D and Laurin M (2007) Fossils, molecules, divergence times, and the origin of lissamphibians. Systematic Biology 56, 369-88. doi: 10.1080/ 10635150701397635

Martill DM, Brito PM and Washington-Evans J (2008) Mass mortality of fishes in the Santana Formation (Lower Cretaceous, ?Albian) of northeast Brazil. Cretaceous Research 29, 649-58. doi: 10.1016/j.cretres.2008.01.012

Martin JE, Deesri U, Liard R, Wattanapituksakul A, Suteethorn S, Lauprasert K, Tong H, Buffetaut E, Suteethorn V, Suan G, Telouk P and Balter V (2015) Strontium isotopes and the long-term residency of thalattosuchians in the freshwater environment. Paleobiology 42, 143-56. doi: 10.1017/pab.2015.42

Martin T (1999) Dryolestidae (Dryolestoidea, Mammalia) aus dem Oberen Jura von Portugal. Abhandlungen der senckenbergischen naturforschenden Gesellschaft 550, 118.

Martin T (2000) The dryolestoids and the primitive "peramurid" from the Guimarota mine. In Guimarota: A Jurassic Ecosystem (eds T Martinand B Krebs), pp. 109-20. Munich: Verlag Dr. Friedrich Pfeil.

Martin T (2001) Mammalian fauna of the Late Jurassic Guimarota ecosystem. Asociación Paleontológica Argentina Publicación Especial 7, 123-6.

Martin T (2002) New stem-lineage representatives of Zatheria (Mammalia) from the Late Jurassic of Portugal. Journal of Vertebrate Paleontology 22, 332-48. doi: 10.1671/0272-4634(2002)022[0332:NSLROZ]2.0.CO;2

Martin T and Krebs B (eds) (2000) Guimarota: A Jurassic Ecosystem. Munich: Verlag Dr. Friedrich Pfeil, 156 pp.

Martínez RN, Apaldetti C, Colombi CE, Praderio A, Fernandez E, Malnis PS, Correa GA, Abelin D and Alcober O (2013) A new sphenodontia (Lepidosauria: Rhynchocephalia) from the Late Triassic of Argentina and the early origin of the herbivore opisthodontians. Proceedings of the Royal Society B, London 280, 2013-57. doi: 10.1098/rspb.2013.2057

Mateer NJ, Wycisk P, Jacobs LL, Brunet M, Luger P, Arush MA, Hendriks F, Weissbrod T, Gvirtzman G, Mbede E, Dina A, Moody RTJ, Weigelt G, ElNakhal HA, Hell J and Stets J (1992) Correlation of nonmarine Cretaceous strata of Africa and the Middle East. Cretaceous Research 13, 273-318. doi: 10.1016/0195-6671(92)90003-9

Matsumoto R, Buffetaut E, Escuillié F, Hervet S and Evans SE (2013) New material of the choristodere Lazarussuchus (Diapsida, Choristodera) from the Paleocene of France. Journal of Vertebrate Paleontology 33, 319-39. doi: 10.1080/02724634.2012.716274

Matsuoka H, Kusuhashi N and Corfe I (2016) A new Early Cretaceous tritylodontid (Synapsida, Cynodontia, Mammaliamorpha) from the Kuwajima Formation (Tetori Group) of central Japan. Journal of Vertebrate Paleontology 36. e1112289, 16 pp. doi: 10.1080/02724634.2016.1112289

Matsuoka H and Setoguchi T (2000) Significance of Chinese tritylodontids (Synapsida, Cynodontia) for the systematic study of Japanese materials from the Lower Cretaceous Kuwajima Formation, Tetori Group of Shiramine, Ishikawa, Japan. Asian Paleoprimatology 1, 161-76.

Metcalf SJ, Vaughan RF, Benton MJ, Cole J, Simms MJ and Dartnall DL (1992) A new Bathonian (Middle Jurassic) microvertebrate site, within the Chipping Norton Limestone Formation at Hornsleaslow Quarry, 
Gloucestershire. Proceedings of the Geologists' Association 103, 321-42. doi: 10.1080/02724634.2017.1363767

Miguel R, Gallo V and Morrone JJ (2014) Distributional pattern of Mawsoniidae (Sarcopterygii: Actinistia). Anais da Academia Brasileira de Ciências 86, 159-70. doi: 10.1590/0001-3765201420130035

Mojon PO, Haddoumi H and Charrière A (2009) Nouvelles données sur les Charophytes et Ostracodes du Jurassique moyen-supérieur de l'Atlas marocain. Carnets de Géologie, Brest, Mémoire 2009/03 , 1-39. doi: 10.4267/2042/29781

Monbaron M (1988) Un serpent de mer: le problème de la datation des 'Couches Rouges' du Haut Atlas marocain. Le point de la situation. Actes de la société jurassienne d'Émulation, 73-92.

Moody RT and Sutcliffe PJC (1991) The Cretaceous deposits of the Iullemmeden Basin of Niger, central West Africa. Cretaceous Research 12, 137-57. doi: 10.1016/S0195-6671(05)80021-7

Nessov LA (1984) Pterosaurs and birds of the Late Cretaceous of Central Asia. Paläontologische Zeitschrift 1, 47-57.

Norell MA and Makovicky PJ (2004) Dromaeosauridae. In The Dinosauria. 2nd edition (eds DB Weishampel, P Dodsonand H Osmólska), pp. 196-209. Berkeley: University of California Press.

Norman DB, Sues H-D, Witmer LM and Coria RA (2004) Basal Ornithopoda. In The Dinosauria. 2nd edition (eds DB Weishampel, $\mathrm{P}$ Dodsonand $\mathrm{H}$ Osmólska), pp. 393-412. Berkeley: University of California Press.

Ostrom JH (1976) Archaeopteryx and the origin of birds. Biological Journal of the Linnean Society 8, 91-182. doi: 10.1111/j.1095-8312.1976.tb00244.x

Paleobiology Database Contributors (2019) PaleoBioDB: The Paleobiology Database. University of Wisconsin at Madison. Available at https://www. paleobiodb.org/ (accessed 8 March 2019).

Patterson C (1993) Osteichthyes: Teleostei. In The Fossil Record 2 (ed. MJ Benton), pp. 622-56. London: Chapman and Hall.

Pierce SE and Benton MJ (2006) Pelagosaurus typus Bronn, 1841 (Mesoeucrocodylia: Thalattosuchia) from the Upper Lias (Toarcian, Lower Jurassic) of Somerset, England. Journal of Vertebrate Paleontology 26, 621-35.

Prasad GVR and Manhas BK (2002) Triconodont mammals from the Jurassic Kota Formation of India. Geodiversitas 24, 445-64.

Prasad GVR and Rage J-C (1991) A discoglossid frog in the latest Cretaceous (Maastrichtian) of India: further evidence for a terrestrial route between India and Laurasia in the latest Cretaceous. Comptes Rendus de l'Académie des Sciences de Paris Série II 313, 273-8.

Rauhut OWM (2000) The dinosaur faun from the Guimarota mine. In Guimarota: A Jurassic Ecosystem (eds T Martinand B Krebs), pp. 75-82. Munich: Verlag Dr. Friedrich Pfeil.

Rauhut OWM (2001) Herbivorous dinosaurs from the Late Jurassic (Kimmeridgian) of Guimarota, Portugal. Proceedings of the Geologists' Association 112, 275-83. doi: 10.1016/S0016-7878(01)80007-9

Rauhut OWM and López-Arbarello A (2009) Considerations on the age of the Tiouaren Formation (Iullemmeden Basin, Niger, Africa): implications for Gondwanan Mesozoic terrestrial vertebrate faunas. Palaeogeography, Palaeoclimatology, Palaeoecology 271, 259-67. doi: 10.1016/j.palaeo.2008.10.019

Rees J and Underwood CJ (2002) The status of the shark genus Lissodus Brough 1935, and the position of nominal Lissodus species within the Hybodontoidea (Selachii). Journal of Vertebrate Paleontology 22, 471-9. doi: 10.1671/02724634(2002)022[0471:TSOTSG]2.0.CO;2

Rees J and Underwood CJ (2008) Hybondont sharks of the English Bathonian and Callovian (Middle Jurassic). Palaeontology 51, 117-47. doi: 10.1111/j. 1475-4983.2007.00737.x

Richter A (1994) Lacertilia aus der Unteren Kreide von Una und Galve (Spanien) und Anoual (Marokko). Berliner Geowissenschaftliche Abhandlungen Reihe E 14, 1-147.

Richter A, Knötschke N, Kosma R, Sobral G and Wings O (2013) The first Mesozoic lizard from northern Germany (Paramacellodidae, Late Jurassic, Langenberg Quarry) and its taphonomy. Journal of Vertebrate Paleontology, Program and Abstracts 2013, 198.

Rogers RR and Brady ME (2010) Origins of microfossil bonebeds: insights from the Upper Cretaceous Judith River Formation of north-central Montana. Palaeobiology 36, 80-112. doi: 10.1666/0094-8373-36.1.80

Sankey JT (2008) Vertebrate paleoecology from microsites, Talley Mountain, Upper Aguja Formation (Late Cretaceous), Big Bend National Park, Texas, USA. In Vertebrate Microfossil assemblages: Their Role in
Paleocology and Paleobiogeography (eds JT Sankeyand S Baszio), pp. 6177. Bloomington: Indiana University Press.

Schudack M (2000) Geological setting and dating of the Guimarota beds. In Guimarota: A Jurassic Ecosystem (eds T Martin and B Krebs), pp. 21-6. Munich: Verlag Dr. Friedrich Pfeil.

Schwarz D (2002) A new species of Goniopholis from the Upper Jurassic of Portugal. Paleontology 45, 185-208. doi: 10.1111/1475-4983.00233

Schwarz D, Raddatz M and Wings O (2017) Knoetschkesuchus langenbergensis gen. nov. sp. nov., a new atoposaurid crocodyliform from the Upper Jurassic Langenberg Quarry (Lower Saxony, northwestern Germany), and its relationships to Theriosuchus. PLoS ONE 12, e0160617. doi: 10.1371/journal.pone. 0160617

Schwarz D and Salisbury SW (2005) A new species of Theriosuchus (Atoposauridae, Crocodylomorpha) from the Late Jurassic (Kimmeridgian) of Guimarota, Portugal. Geobios 38, 779-802. doi: 10. 1016/j.geobios.2004.04.005

Schwarz-Wings D, Rees J and Lindgren J (2009) Lower Cretaceous mesoeucrocodylians from Scandinavia (Denmark and Sweden). Cretaceous Research 30, 1345-55.

Sereno PC, Beck AL, Dutheil DB, Larsson HCE, Lyon GH, Moussa B, Sadleir RW, Sidor CA, Varrichio DJ, Wilson GP and Wilson JA (1999) Cretaceous sauropods from the Sahara and the uneven rate of skeletal evolution among dinosaurs. Science 286, 1342-7. doi: 10.1126/science.286.5443.1342

Sereno PC, Wilson JA and Conrad JL (2004) New dinosaurs link southern landmasses in the mid-Cretaceous. Proceedings of the Royal Society B, London 271, 1325-30. doi: 10.1098/rspb.2004.2692

Sereno PC, Wilson JA, Larsson HCE, Dutheil DB and Sues H-D (1994) Early Cretaceous dinosaurs from the Sahara. Science 266, 267-71. doi: 10.1126/ science.266.5183.267

Setoguchi T, Matsuda M and Matsuoka H (1999) New discovery of an Early Cretaceous tritylodontid (Reptilia, Therapsida) from Japan and the phylogenetic reconstruction of Tritylodontidae based on the dental characters. In Proceedings of the Seventh Annual Meeting of the Chinese Society of Vertebrate Paleontology (eds YQ Wangand T Deng), pp. 117-214. Beijing: China Ocean Press.

Sezgin M and Sankur B (2004) Survey over image tresholding techniques and quatitative performance evaluation. Journal of Electronic Imaging 13, 146-65.

Sigogneau-Russell D (1989) Découverte du premier Symmétrodonte du continent africain. Comptes Rendus de l'Académie des Sciences de Paris Série II 309, 921-6.

Sigogneau-Russell D (1991a) Nouveaux Mammifères thériens du Crétacé inférieur du Maroc. Comptes Rendus de l'Académie des Sciences de Paris Série II 313, 279-85.

Sigogneau-Russell D (1991b) First evidence of Multituberculata (Mammalia) in the Mesozoic of Africa. Neues Jahrbuch für Geologie und Paläontologie, Monatshefte 2, 119-25.

Sigogneau-Russell D (1991c) Découverte du premier mammifère tribosphénique du Mésozoïque africain. Comptes Rendus de l'Académie des Sciences de Paris Série II 313, 1635-40.

Sigogneau-Russell D (1992) Hypomylos phelizoni nov. gen. nov. sp., une étape précoce de l'évolution de la molaire tribosphénique (Crétacé basal du Maroc). Geobios 25, 389-93. doi: 10.1016/0016-6995(92)80011-2

Sigogneau-Russell D (1995a) Further data and reflexions on the tribosphenid mammals (Tribotheria) from the Early Cretaceous of Morocco. Bulletin du Muséum national d'Histoire naturelle de Paris, $4 e$ série, section $C \mathbf{1 6}$, 291-312.

Sigogneau-Russell D (1995b) Two possibly aquatic triconodont mammals from the Early Cretaceous of Morocco. Acta Palaeontologica Polonica 40, 149-62.

Sigogneau-Russell D (1999) Réévaluation des Peramura (Mammalia, Cladotheria) sur la base de nouveaux spécimens du Crétacé inférieur d'Angleterre et du Maroc. Geodiversitas 21, 93-127.

Sigogneau-Russell D (2003) Diversity of triconodont mammals from the Early Cretaceous of North Africa: affinities of the amphilestids. Palaeovertebrata 32, 27-55.

Sigogneau-Russell D and Ensom PC (1994) Découverte, dans le groupe de Purbeck (Berriasien, Angleterre) du plus ancien témoignage de l'existence de mammifère tribosphéniques. Comptes Rendus de l'Académie des Sciences de Paris, Série II 319, 833-8. 
Sigogneau-Russell D and Ensom PC (1998). Thereuodon (Theria, Symmetrodonta) from the Lower Cretaceous of Africa and Europe, and a brief review of symmetrodonts. Cretaceous Research 19, 445-70. doi: 10. 1006/cres.1998.0115

Sigogneau-Russell D, Evans SE, Levine JF and Russell DA (1998) The Early Cretaceous microvertebrate locality of Anoual, Morocco: a glimpse at the small vertebrate assemblages of Africa. In Lower and Middle Cretaceous Terrestrial Ecosystems (eds SG Lucas, JI Kirklandand JW Estep), pp. 17782. New Mexico Museum of Natural History and Science no. 14.

Sigogneau-Russell D, Monbaron M and de Kaenel E (1990) Nouvelles données sur le gisement à Mammifères mésozoïques du Haut-Atlas marocain. Geobios 23, 461-83. doi: 10.1016/S0016-6995(06)80272-X

Sigogneau-Russell D, Monbaron M and Russell DE (1988) Découverte de mammifères dans le Mésozoïque moyen d'Afrique. Comptes rendus de l'Académie des Sciences de Paris Série II 307, 1045-50.

Simpson GG (1926) Mesozoic Mammalia. V. Dromatherium and Microconodon. American Journal of Science 12, 87-108. doi: 10.2475/ajs. s5-12.68.87

Skutschas PP (2016) A new crown-group salamander from the Middle Jurassic of Western Siberia, Russia. Palaeobiodiversity and Palaeoenvironments 96, 41-8. doi: 10.1007/s12549-015-0216-X

Skutschas PP, Kolchanov VV, Averianov AO, Martin T, Schellhorn R, Kolosov PN and Vitenko DD (2018) A new relict stem-group salamander from the Early Cretaceous of Yakutia, Russia. Acta Palaeontologica Polonica 63, 519-25. doi: 10.4202/app.00498.2018

Soto M and Perea D (2010) Late Jurassic lungfishes (Dipnoi) from Uruguay, with comments on the systematics of Gondwanan ceratodontiforms. Journal of Vertebrate Paleontology 30, 1049-58. doi: 10.1080/02724634. 2010.483540

Stampfli GM and Borel GD (2002) A plate tectonic model for the Paleozoic and Mesozoic constrained by dynamic plate boundaries and restored synthetic oceanic isochrones. Earth and Planetary Science Letters 196, 17-33. doi: 10.1016/S0012-821X(01)00588-X

Sues HD (2001) On Microconodon, a Late Triassic cynodont from the Newark supergroup of eastern North America. Bulletin of the Museum of Comparative Zoology 156, 37-48.

Sues HD, Olsen PE, Kroehler PA (1994) Small tetrapods from the Upper Triassic of the Richmond basin (Newark Supergroup), Virginia. In In the Shadow of the Dinosaurs: Early Mesozoic Tetrapods (eds NC Fraserand HD Sues), pp. 161-70. Cambridge: Cambridge University Press.

Sulej T, Niedźwiedzki G, Tałanda M, Dróżdż D, Hara E (2018) A new early Late Triassic non-mammaliaform eucynodont from Poland. Historical Biology, published online 5 June 2018, 13 pp. doi: 10.1080/08912963.2018.1471477

Sweetman SC (2006) A gobiconodontid (Mammalia, Eutriconodonta) from the Early Cretaceous (Barremian) Wessex Formation of the Isle of Wight, southern Britain. Palaeontology, 49, 889-97. doi: 10.1111/j.1475-4983. 2006.00564.x

Sweetman SC (2016) A comparison of Barremian-early Aptian vertebrate assemblages from the Jehol Group, north-east China and the Wealden Group, southern Britain: the value of microvertebrate studies in adverse preservational settings. Palaeobiodiversity and Palaeoenvironments 96, 149-67. doi: 10.1007/s12549-015-0217-9

Sweetman SC and Martill DM (2010) Pterosaurs of the Wessex Formation (Early Cretaceous, Barremian) of the Isle of Wight, southern England: a review with new data. Journal of Iberian Geology 36, 225-42.

Swennen C and Yu T (2004) Notes on feeding structures of the black-faced spoonbill Platalea minor. Ornithological Science 3, 119-24. doi: 10.2326/ osj.3.119

Taquet P (1976) Géologie et Paléontologie du Gisement de Gadoufaoua (Aptien du Niger). Paris: Cahiers de Paléontologie, Éditions du Centre National de la Recherche Scientifique, 247 pp.

Tatarinov LP and Mashchenko EN (1999) A find of an aberrant tritylodont (Reptilia, Cynodontia) in the Lower Cretaceous of the Kemerovo region. Paleontologicheskii Zhurnal 4, 91-2.

Tennant JP and Mannion PD (2014) Revision of the Late Jurassic crocodyliform Alligatorellus, and evidence for allopatric speciation driving high diversity in western European atoposaurids. PeerJ 2:e599, 37 pp. doi: $10.7717 /$ peerj.599
Tennant JP, Mannion PD and Upchurch P (2016) Evolutionary relationships and systematics of Atoposauridae (Crocodylomorpha: Neosuchia): implications for the rise of Eusuchia. Zoological Journal of the Linnean Society 177, 854-936. doi: 10.1111/zoj.12400

Tennant JP, Mannion PD, Upchurch P, Sutton MD and Price GP (2016) Biotic and environmental dynamics through the Late Jurassic-Early Cretaceous transition: evidence for protracted faunal and ecological turnover. Biological Reviews 92, 776-814. doi: 10.1111/brv.12255

Thies D (1995) Placoid scales (Chondrichthyes: Elasmobranchii) from the Late Jurassic (Kimmeridgian) of northern Germany. Journal of Vertebrate Paleontology 15, 463-81. doi: 10.1080/02724634.1995.10011242

Thulborn RA (1973) Teeth of ornithischian dinosaurs from the Upper Jurassic of Portugal, with description of a hypsilophodontid (Phyllodon henkelli gen. et sp. nov.) from the Guimarota lignite. Memória dos Serviços Geológicos de Portugal 22, 89-134.

Unwin DM (1988) New pterosaurs from Brazil. Nature 332, 398-9.

Unwin DM (2005) The Pterosaurs: From Deep Time. New York: Pi Press, 352 pp.

Vallone ER, Vezzosi RI and Cione AL (2017) First fossil fishes (Teleostei, Siluriformes) from the Late Pleistocene of Santa Fe Province, Argentina. Alcheringa 41, 369-77. doi: 10.1080/03115518.2017.1288828

Veldmeijer AJ, Signore M and Bucci E (2006) Predator-prey interaction of Brazilian Cretaceous toothed pterosaurs: a case example. In Predation in Organisms: A Distinct Phenomenon (ed. AMT Elewa), pp. 295-308. Berlin: Springer-Verlag.

Vignaud P (1997) La moprhologie dentaire des Thalattosuchia (Crocodylia, Mesosuchia). Palaeovertebrata 26, 35-59.

Vrielynck B, Dercourt J and Cottereau N (1995) The Tethys: an ocean broken by seuils lithospheriques. In The Tethys Ocean, Vol. 8: The Ocean Basins and Margins (eds AEM Naim, L-E Ricou, B Vrielynckand J Dercourt), pp. 495511. New York: Plenum Press.

Vullo R (2007) Les vertébrés du Crétacé supérieur des Charentes (Sud-Ouest de la France): biodiversité, taphonomie, paléoécologie et paléobiogéographie. Mémoires de Géosciences Rennes 125, 1-302.

Vullo R, Abit D, Ballèvre M, Billon-Bruyat J-P, Bourgeais R, Buffetaut E, Daviero-Gomez V, Garcia G, Gomez B, Mazin J-M, Morel S, Néraudeau D, Pouech J, Rage J-C, Schnyder J and Tong H (2014) Palaeontology of the Purbeck-type (Tithonian, Late Jurassic) bonebeds of Chassiron (Oléron Island, western France). Comptes Rendus Palevol 13, 421-41. doi: 10.1016/j.crpv.2014.03.003

Vullo R and Courville P (2014) Fish remains (Elasmobranchii, Actinopterygii) from the Late Cretaceous of the Benue Trough, Nigeria. Journal of African Earth Sciences 97, 194-206. doi: 10.1016/j.jafrearsci.2014.04.016

Wenz S and Poyato-Ariza FJ (1994) Les Actinoptérygiens juveniles du Crétacé inférieur du Montsec et de Las Hoyas (Espagne). Geobios 27, 203-12. doi: 10. 1016/S0016-6995(94)80035-9

Wiechmann MF (2000) The albanerpetontids from the Guimarota mine. In Guimarota: A Jurassic Ecosystem (eds T Martinand B Krebs), pp. 51-54. Munich: Verlag Dr. Friedrich Pfeil.

Wings O (2015) The Langenberg Quarry near Goslar: unique window into a terrestrial Late Jurassic ecosystem in Northern Germany. In Abstracts of the 12th Symposium of Mesozoic Terrestrial Ecosystems, Shenyang, China, 16-20 August 2015 (eds Y Zhang, SZ Wuand G Sun), pp. 99-100.

Wings $O$ and Sander PM (2012) The Late Jurassic vertebrate assemblage of the Langenberg Quarry, Oker, Northern Germany. Fundamental 20, 281-4.

Witton MP (2013) Pterosaurs: Natural History, Evolution, Anatomy. Princeton: Princeton University Press, 304 pp.

Witton MP (2018) Pterosaurs in Mesozoic food webs: a review of fossil evidence. In New Perspectives on Pterosaur Palaeobiology (eds DWE Hone, MP Witton and DM Martill), pp. 7-23. Geological Society of London, Special Publication no. 455.

Xu GH, Zao LJ and Coates MI (2014) The oldest ionoscopiform from China sheds new light on the early evolution of halecomorph fishes. Biology Letters 10, 2014.0204. doi: 10.1098/rsbl.2014.0204

Young MT, Tennant JP, Brusatte SL, Challands TJ, Fraser NC, Clark ND and Ross DA (2016) The first definitive Middle Jurassic atoposaurid (Crocodylomorpha, Neosuchia), and a discussion on the genus Theriosuchus. Zoological journal of the Linnean Society 176, 443-62. doi: 10.1111/zoj.12315 
Zhou Z (2004) The origin and early evolution of birds: discoveries, disputes, and perspectives from fossil evidence. Natuwissenschaften 91, 455-71. doi: 10. 1007/s00114-004-0570-4

Zinke J (1998) Small theropod teeth from the Upper Jurassic coal mine of Guimarota (Portugal). Paläontologische Zeitschrift 72, 179-89.
Zouhri S, Sigogneau-Russell D and Haddoumi H (2017) Microvertébrés de la transition Jurassique-Crétacé du synclinal d'Anoual (Haut Atlas Oriental), Maroc. In Paléontologie des Vertébrés du Maroc: état des connaissances (ed. S Zouhri), pp. 285-306. Mémoires de la Société géologique de France 180. 